\title{
European Goods Market Integration in the Very Long Run: From the Black Death to the First World War
}

\author{
Giovanni Federico, MaX-Stephan Schulze, and Oliver Volckart
}

This paper examines price convergence and changes in the efficiency of wheat markets, covering the period from the mid-fourteenth to the early twentieth century and most of Europe. The analysis is based on a new data set of prices from almost 600 markets. Unlike previous research, we find that convergence was a predominantly pre-modern phenomenon. It started in the late fifteenth century, advanced rapidly until the beginning of the seventeenth century when it temporarily stalled, resumed after the Thirty Years' War, and accelerated after the Napoleonic Wars in response to trade liberalization. From the late 1840s, convergence petered out and turned into divergence after 1875 as policy decisions dominated technological change. Our results point to the 'Little Divergence' between North-Western Europe and the rest of the continent as starting about 1600. Long-term improvements in market efficiency began in the early sixteenth century, with advances over time being as uneven as in price convergence. We trace this to differential institutional change and the non-synchronous spread of modern media and systems of information transmission that affected the ability of merchants to react to news.

E conomic historians have always regarded the expansion of markets and the resulting increase in the division of labor and specialization as powerful sources of growth, especially in pre-industrial Europe (Kelly 1997; Epstein 2000; Malanima 2009; Persson 2010; Chilosi et al. 2013; for dissenting voices, see Clark 2007; Bateman 2012; van Bavel 2016). Some have also argued that the development of better integrated markets

The Journal of Economic History, Vol. 81, No. 1 (March 2021). (C) The Economic History Association. All rights reserved. doi:

Max-Stephan Schulze (corresponding author) is Professor, London School of Economics, Department of Economic History-Economic History Department, Houghton Street, London WC2A 2AE, United Kingdom of Great Britain and Northern Ireland. E-mail: m.s.schulze@ lse.ac.uk. Giovanni Federico is Professor, New York University Abu Dhabi, Division of Social Sciences, NYU Campus Saadiyat Island Abu Dhabi (UAE). E-mail: gf63@nyu.edu. Oliver Volckart is Professor, London School of Economics and Political Science-Economic History Department, Houghton Street, London WC2A 2AE, United Kingdom of Great Britain and Northern Ireland. E-mail: o.j.volckart@1se.ac.uk.

Generous research support by the European Research Council (ERC-grant 230484) is gratefully acknowledged. The authors also thank David Chilosi, Sara Pecchioli, and Coskun Tuncer, for excellent research assistance, and Walter Bauernfeind, who has shared with us the Nuremberg price series, one of the longest in the data set. Earlier versions of this paper were presented at Berlin (Humboldt University); Bologna, Copenhagen, Dublin, and Madrid (Carlos III and CUNEF); and Prato (Istituto Datini). We thank the participants for helpful comments and suggestions. 
in England and the Dutch Republic since the seventeenth century contributed crucially to the Little Divergence between these countries and the rest of Europe (Allen 2001; Fouquet and Broadberry 2015). Market integration, thus, has been placed squarely at the center of the economic development of Europe. Whether it deserves this place is difficult to test. Historians have spent decades investigating qualitative sources, such as legal codes or contracts concluded between merchants (evidence that is difficult to quantify), to examine the development of trade and markets. Even when they used sources that contained quantitative data (e.g., merchant books of account), they rarely collected and analyzed them econometrically. We, therefore, know far less about the quantitative than the qualitative aspects of European commerce. ${ }^{1}$

This is why economic historians have increasingly turned to price data. Wheat prices especially are among the best quantitative evidence available: they are abundant and, given the fairly homogenous nature of wheat, relatively easy to standardize. Spreads between prices in different locations persistently above the commodity points (i.e., the trade costs, possibly adjusted for arbitrage risk) would suggest that merchants left opportunities for arbitrage unexploited and, therefore, that trade would be less intensive than otherwise possible. Moreover, where prices on different markets moved in step, this was probably the result of merchants using the same information to make decisions about buying and selling commodities. Hence, analyzing price differentials systematically helps compensate for the lack of evidence on actual trade flows.

Historians broadly agree on nineteenth- and twentieth-century trends in trade identified in this way. By contrast, a consensus on when, how far, and how quickly markets integrated across Europe and over the very long term, let alone about why they did so, is still lacking. In particular, findings on the timing of pre-modern integration differ widely-unsurprisingly so, given that research has so far failed to agree on a number of central methodological points. There is neither a consistent and precise definition of integration nor agreement on what measures of integration to use (Fackler and Goodwin 2001, pp. 976-81). Moreover, the results of empirical work are hard to compare because scholars have focused on different product markets, regions, and time periods and used different econometric techniques (Federico 2012a).

\footnotetext{
${ }^{1}$ From the late Middle Ages onward, a growing number of customs registers have been preserved, some of which have been examined in this context (cf. Carus-Wilson and Coleman, 1963). The most comprehensive are the Sound-Toll-Registers (cf. Christiansen 1934; http://www. soundtoll.nl/index.php/en/over-het-project/str-online) that cover the years from 1497 to 1857.
} 
This paper builds on an extensive new wheat price data set that covers far more markets, a wider geographical area (most of Europe), and a longer period of time (from the Black Death to the First World War) than any previous analyses. ${ }^{2}$ The focus of the paper is on measuring and documenting wheat market integration in Europe. We study two dimensions of integration: price convergence, a decrease in price differentials between markets, and improvements in market efficiency. "Semi-strong efficiency" is taken to refer to the extent to which prices reflect publicly available and relevant information. In an "efficient" market, there are no opportunities left for arbitrage. The market integration literature typically proceeds from the assumption that agents know prices and conditions in their own as well as other locations. If a shock causes price differentials within well-integrated markets to diverge from their equilibrium level, arbitrage would restore the equilibrium price gap. The faster this process, the more efficient is the market (Federico 2012a, 2019). Price convergence and adjustment to shocks do not necessarily move in step. They require separate analyses with different statistical techniques and may give rise to different views of historical integration processes. We address two core questions: First, when and by how much did wheat prices converge? Second, to what extent, if any, did markets become more efficient over time?

In contrast to previous work in the field, we find that price convergence in Europe was a long-term process that began in the mid-fifteenth and continued (with accelerations and setbacks) to the mid-nineteenth century. We also find that convergence was associated with an improvement in market efficiency, approximated by co-movements in prices, from the early sixteenth century onward (likewise with temporary setbacks). The paper proceeds as follows. The next section reviews the recent literature on long-run market integration in Europe. We then set out the intuition of our approach and empirical strategy in the second section. The third section describes the extensive new data set, while the fourth section discusses the main results on price convergence and co-movement. The fifth section compares the timing of these two dimensions of integration and suggests some hypotheses to account for the similarities and differences observed. This section emphasizes the role of conflicts and better communications such as the development of postal networks and newspapers. The conclusion draws attention to the main implications of the new results.

\footnotetext{
${ }^{2}$ Froot, Kim, and Rogoff (1995) examine a similar span of time but analyze integration between England and the Netherlands only. Chilosi et al. (2013) and Studer (2015) cover the period from the early seventeenth to the late nineteenth centuries only.
} 


\section{LITERATURE SURVEY}

The statistical analysis of market integration dates back to the 1950s (Achilles 1959), but research in this field has come into its own only since about the turn of the last century. While about half of the studies published between 2009 and 2012 concern the modern world (Federico 2012a), it is striking that market integration is one of the few topics where quantitative methods have made major inroads into research on premodern economic history. This has been possible because of the extensive preservation of price data from the pre-statistical age. However, most of these studies focus on short periods, especially those on the eighteenth century, and on individual European countries such as France (Tilly 1971; Chevet and Saint Amour 1991; Roehner 1994; Chevet 1996, O'Grada and Chevet 2002). The few long-term, Europe-wide papers agree neither on the timing nor the pace of integration. The pioneering work by Achilles (1959) identifies increasing integration all over Europe from 1550 to 1700, while Allen and Unger (1990) and Persson (1999) find an emerging integrated European wheat market in the eighteenth century. On the other hand, van Bochove (2007) and Özmucur and Pamuk (2007) rule out any such integration from the seventeenth to the beginning of the nineteenth century. Area studies, too, yield mixed results. For instance, Jacks (2004) finds no clear trends in the Baltic before 1640, disintegration in 1640 1670 , and re-integration in the eighteenth century. The most recent studies do not settle the issue. Chilosi et al. (2013) and Studer (2015) focus on the period from the seventeenth to the late nineteenth or early twentieth century. They observe a trend toward price convergence in the early modern period, especially from the late seventeenth to the mid-eighteenth century. Their measure of efficiency (i.e., the co-movement of prices across markets), though, remains almost constant until the late eighteenth century. Drawing on a smaller number of markets, Bateman $(2011,2012)$ estimates 50-year averages of price gaps since 1400. Bateman's averages remained large until 1500 and thereafter moved erratically: they declined in 1500-1549, increased in 1550-1600, declined again in 1600-1649, rebounded in 1650-1700, hit a trough in 1700-1749, and increased again in the second half of the eighteenth century. Contradicting most other studies (Jacks 2005; Federico and Persson 2007; Federico 2011; Chilosi et al. 2013), Bateman argues that price gaps remained large in the first half of the nineteenth century and collapsed only between 1849 and 1900 (Bateman 2012). These conflicting results reflect the use of different data sets covering different markets and periods. Most works rely on small samples whose composition changes over time. For instance, Bateman (2011) quotes price series from 46 markets, but many of them have 
extensive gaps in observations. ${ }^{3}$ Chilosi et al. (2013) find a substantial difference in dispersion of prices between a balanced sample of 13 markets and a wider unbalanced sample of about 60 markets in the nineteenth century. Though following by and large similar trends, the coefficient of variation of their balanced sample was consistently smaller than that of the unbalanced sample. Sample composition evidently matters.

\section{EMPIRICAL STRATEGY}

Mapping price convergence is fairly uncontroversial. A standard measure is the coefficient of variation, which gives the dispersion of prices across markets in a given year. It is easy to compute and comparable across time and space for the same product and allows comparisons of convergence patterns between different products. Moreover, it is reasonably robust to quality differentials for fairly homogenous products such as wheat. Ideally, prices should refer to the same quality, but biases from quality differentials and from their changes in time are not systematic and they may well cancel out each other (Federico 2011). ${ }^{4}$

Selecting a measure of efficiency is less straightforward. The basic idea is to examine to what extent and how quickly prices across localities re-adjusted after shocks such as crop failures, wars, or the conclusion of trade treaties. Efficiency is, thus, indicated by the extent to which prices on several markets move in line with each other. The reaction to price shocks can be estimated with different versions of autoregressive models for pairs of markets (Federico 2012a, 2019). However, results are meaningful only if the frequency of the series (say, in months) is higher than the expected

\footnotetext{
${ }^{3}$ Bateman estimates price gaps with a fixed-effect panel regression, with relative prices between pairs of markets as the dependent variable, explained by time dummies. She computes price gaps between all markets of a "country" (in late nineteenth-century borders) and markets in the rest of Europe and then obtains the European gap as a mean of country-specific gaps. For instance, her "Italy" includes Tuscany (1263-1859-itself a composite series of prices in Pisa and Florence), Naples (1474-1893), Sansepolcro (1500-1631), Catania (1512-1630), Udine (1600-1825), Milan (1700-1860), Ancona (1700-1825), and Pesaro (1700-1825). These markets belonged to the same polity only after 1860 .

${ }^{4}$ The coefficient of variation would be biased upward if the difference between the available price and the "true," quality-adjusted one is positive (i.e., the quality of the quoted wheat is better than the "reference" one) in high-price markets or if it is negative in low-price markets. The coefficient would be biased downward in the opposite case but only if the difference in qualityadjusted prices exceeds in absolute value the quality gap. Therefore, the coefficient of variation is more likely to be upward than downward biased. This bias would be smaller the greater the differences in quality-adjusted price differentials are relative to quality differentials. This implies that quality differentials are a problem, especially in highly integrated markets. An improvement in quality of wheat traded relative to the reference ones would bias upward the coefficient of variation in high price markets, but it would bias it downward in low price ones. The effect of a worsening of relative quality would be the opposite, and the net effect is unpredictable.
} 
reaction time (Taylor 2001; Brunt and Cannon 2014) and if there is trade between markets. For most historical cases, the evidence on trade flows and time of adjustment is too scarce to assess either condition. It is, though, unlikely that prices took more than a year to adjust and, thus, autoregressive models with annual data would yield biased results. For this reason, we rather approximate market efficiency by its outcome, that is, by the degree of co-movement in prices. The more efficient a market, the less likely are permanent equilibrium price differentials between different locations. The previous literature focused on co-movements between pairs of markets (Federico 2012a). Here, we consider co-movements between all price series drawing on dynamic factor analysis (DFA). In a nutshell, it is a dynamic version of principal component analysis. DFA allows extracting endogenously the common shocks affecting any number of price series and measures the degree of co-movement between this common component and local market-specific shocks (Kose, Otrok, and Whiteman 2003). In effect, the technique permits deriving a synthetic sample-wide "price" in relation to which we can assess the adjustment of local markets.

More formally, we decompose the residual from (Hodrick-Prescott) filtered series of prices $\mathrm{HP}_{i t}{ }^{5}$

$$
\mathrm{HP}_{i t}=\lambda_{i} c_{t}+u_{i t}
$$

where $c_{t}$ is the shock common to all price series at time $t, \lambda_{i}$ ("loading") is a time-invariant feature of the ith market, and $u_{i t}$ represents the timevarying and market-specific residuals. The expression $\lambda_{i} c_{t}$ measures the contribution of common shocks to market-specific shocks in year $t$. Thus, the degree of co-movement between each market and the common component (or factor) over the entire period of estimation can be measured by the share in total variance:

$$
\tau_{i}=\lambda_{i}^{2} \times \operatorname{var}\left(c_{t}\right) / \operatorname{var}\left(\mathrm{HP}_{i t}\right) .
$$

A sample-wide (synthetic) measure of efficiency $T_{i}$ can be obtained as an average of market-specific ratios $\tau_{i}$. We set the few cases of negative loading $\left(\lambda_{i}<0\right)$ to zero. They correspond to a negative correlation with the common factor, but they yield a positive $\tau$ and, thus, including them would overstate the degree of co-movement. ${ }^{6}$

\footnotetext{
${ }^{5}$ We follow Ravn and Uhlig's (2002) recommendation and use a smoothing parameter of 6.25 for annual data, which is close to the value of 10 suggested by Baxter and King (1999).

${ }^{6}$ In principle, one could estimate a DFA model with several common components-for example, by adding a national or regional component to the overall, that is, sample-wide, component (Uebele 2011). However, given changes in political geography, grouping markets according to political boundaries would be historically problematic. More importantly, this would distract from the focus on market integration across Europe. Hence, we consider only one common component and run the DFA model over rolling windows.
} 


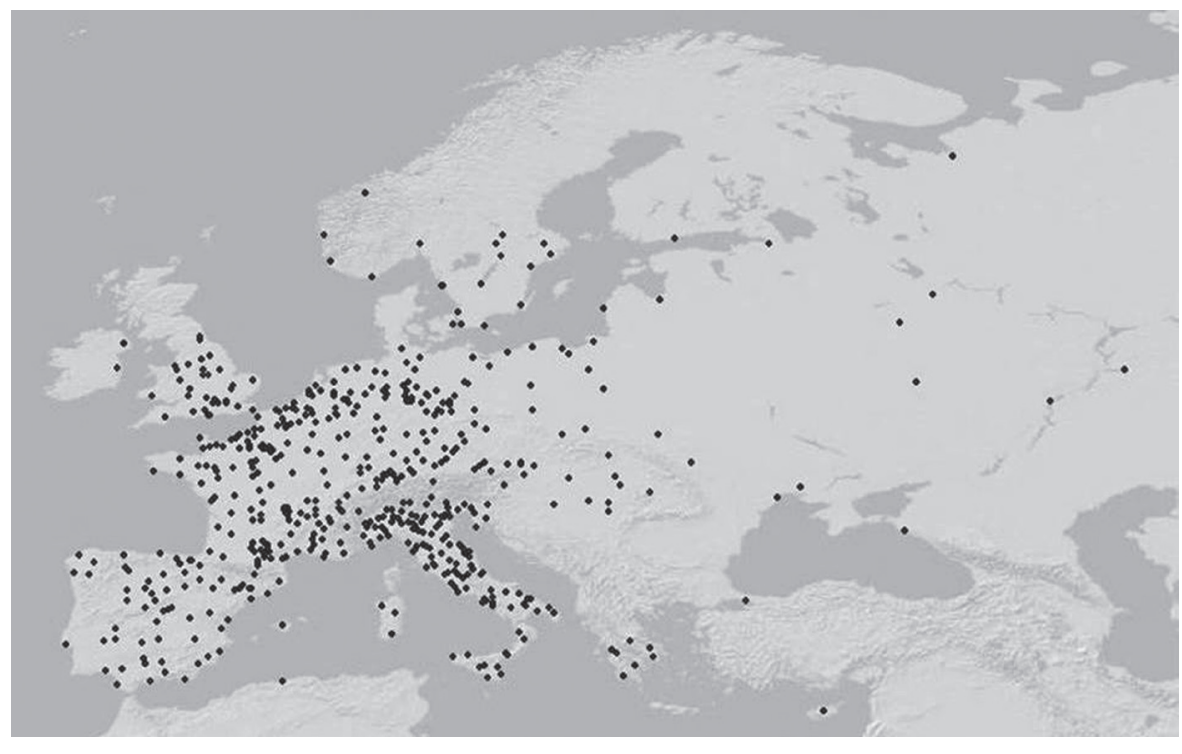

MAP 1

TOTAL SAMPLE: ALL MARKETS

Sources: Authors' own elaboration. Underlying map: Esri. "World Light Grey Base" [basemap]. Scale Not Given. January 31, 2015.

\section{DATA}

The new wheat price data set includes more than 68,000 price observations from more than 580 locations for 1348-1913, thus going far beyond what earlier studies were able to exploit (Federico, Schulze, and Volckart 2020). It covers almost the entire continent from Portugal to Russia, though most of the markets cluster in the territories of modern Belgium, France, Germany, Italy, and the Netherlands (Map 1).

The data have been collected from a wide range of sources and we have benefited particularly from the late eighteenth-century interest in grain prices. Many journals and monographs appearing in the context of the Enlightenment did not only contain extensive discussions of grain price formation-Unger (1752) is a well-known example-but also published price series that in some cases stretch back for centuries (e.g., Anonymous 1765; Wüllen 1771; Brüggemann 1800). Much of this material has not been used by economic historians before.

Almost all historical sources report only one price of "wheat" for each location and the few other sources distinguish at best different provenances (e.g., "domestic" versus "Baltic" in Amsterdam). ${ }^{7}$ Note that it was

\footnotetext{
${ }^{7}$ In the small number of cases in which prices of different qualities or types of wheat are listed for a particular market (e.g., Emden and Nordhausen in Germany), we took the average.
} 
not before the late nineteenth century that standardized quality grading was introduced and prices began to refer to specific grain grades (Velkar 2010, pp. 23-24). Differences in quality across markets and changes over time can potentially affect our measure of price dispersion. However, as set out above, any resulting biases are undetermined over the long run, are not necessarily systematic, and can cancel out (see the Empirical Strategy section).

All prices are converted to grams of silver per hectoliter. ${ }^{8}$ For the period before the establishment of the international gold standard in the 1870s, conversions are based on the pure silver content of the coinage used locally. We use the content of the largest denomination, as people typically did not use small change to buy grain. Changes in the pure silver content of currencies through debasements and (rarer) reinforcement were fully taken into account. For the post- 1870 gold standard period, using the pure silver content of the coinage would not have made much sense. Here, we draw on exchange rates between the local currency and the Pound sterling in combination with London silver prices. All prices have been aggregated at the level of calendar years if they were originally recorded in a frequency or applied to harvest years; they are, thus, comparable in the cross section and over time. ${ }^{9}$

The number of available price series increases over time, reaching a maximum of 300 different markets in the eighteenth century. Intertemporal changes in the geographical coverage, i.e., sample composition, would likely bias the results of any analysis that draws on all series in the data set ("unbalanced sample"). In the interest of consistency and as a means of avoiding these biases, we constructed different "balanced" samples, each including a constant set of markets over time. The analysis relies on a long-run balanced sample of 15 markets for 1450-1913 (Map 2) and a larger balanced sample of 31 markets that covers the period 1508-1785 (Map 3). A further set of seven overlapping period-specific balanced samples for 80 -year periods is designed to maximize the

\footnotetext{
${ }^{8}$ This follows standard practice in the literature for want of an obvious alternative. The simplifying assumption is that silver markets were reasonably well integrated. In the given context, this assumption seems justifiable as the weight-value ratio of bullion was more favorable than for any other goods, suggesting that, in all likelihood, bullion markets were better integrated than others (Chilosi and Volckart 2011).

${ }^{9}$ Most of our sources report calendar year prices. This is in line with Gerhard and Kaufhold's (1990, pp. 6-7) observations on pre-modern recording practice. In the far fewer cases of monthly or quarterly price data, we used annual averages. Where data were reported for harvest years, we assumed that the typical harvest took place in August and computed weighted calendar year averages. Albers, Pfister, and Uebele (2018, pp. 62-82) offer a detailed econometric treatment of the issue with respect to German prices.
} 


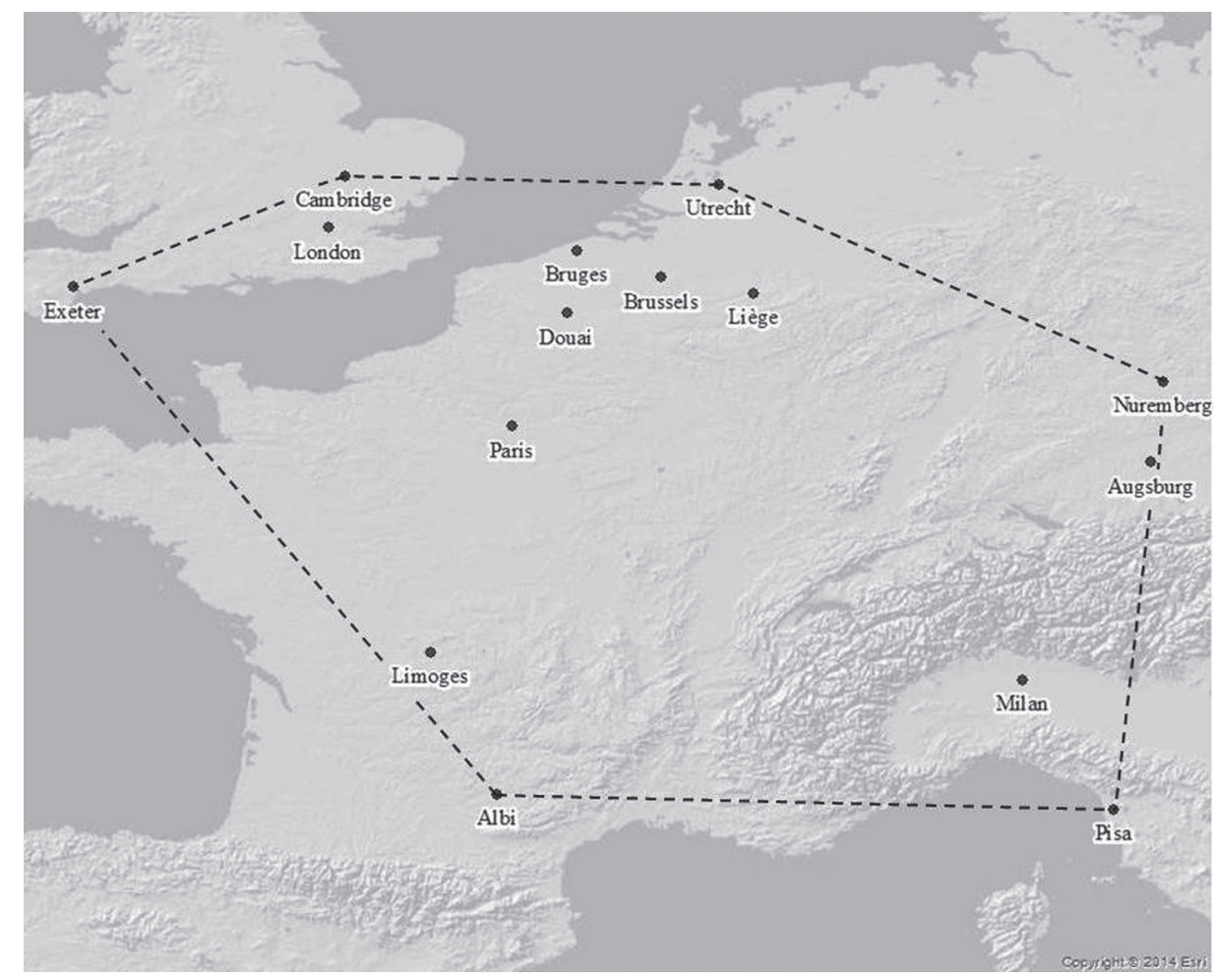

MAP 2

LONG-RUN BALANCED SAMPLE: 15 MARKETS

Note: The dotted line defines the area covered in the construction of a subset of markets from the period-specific samples (see the Results: Convergence and Co-Movement section).

Sources: Authors' own elaboration. Underlying map: Esri. "World Light Grey Base" [basemap]. Scale Not Given. January 31, 2015

number of markets represented. ${ }^{10}$ In order to ensure as even as possible geographical coverage in the seven samples, we first superimposed a grid of 100 by 100 kilometer cells onto the European map. In the next step, we checked whether any cell contained more than one market; wherever that was the case, we retained that market whose distance to markets in neighboring grid cells is largest. The procedure serves to minimize over- or under-representation of regions. Its advantage is that it does not impose a priori segmentation into periods assumed to be historically significant. It also avoids geographical clustering of markets along political borders,

${ }^{10}$ See Online Appendix Table A.1 for a list of markets. Note that only markets with at least 95 percent of observations available for the relevant time period have been selected for the sample. We interpolate the missing data (up to a maximum of 5 percent) with a TRAMO routine (cf. Gómez and Maravall 1996). The choice of 80-year samples is a pragmatic compromise, reflecting the desire to maximize the number of markets with unbroken price series and the need to work with periods of a length sufficient to derive historically meaningful results. 
TABLE 1

BALANCED SAMPLES: NUMBER OF OVERLAPPING MARKETS

\begin{tabular}{lcccccccccc}
\hline \hline & $\begin{array}{c}\text { Long } \\
\text { Run }\end{array}$ & \multicolumn{8}{c}{ Period Specific } \\
\cline { 3 - 11 } & $1450-$ & $1430-$ & $1508-$ & $1581-$ & $1644-$ & $1706-$ & $1772-$ & $1834-$ & $1508-$ \\
& 1913 & 1509 & 1587 & 1660 & 1723 & 1785 & 1851 & 1913 & 1785 \\
\cline { 2 - 11 } Sample Size & 15 & 13 & 32 & 52 & 88 & 116 & 84 & 102 & 31 \\
\hline $1430-1509$ & 9 & - & 9 & 8 & 9 & 11 & 10 & 7 & \\
$1508-1587$ & 11 & - & - & 23 & 22 & 24 & 17 & 13 & 23 \\
$1581-1660$ & 12 & - & - & - & 44 & 44 & 29 & 18 & 28 \\
$1644-1723$ & 13 & - & - & - & - & 75 & 46 & 31 & 29 \\
$1706-1785$ & 15 & - & - & - & - & - & 60 & 36 & 30 \\
$1772-1851$ & 13 & - & - & - & - & - & - & 45 & 22 \\
$1834-1913$ & 9 & - & - & - & - & - & - & - & 14 \\
\hline
\end{tabular}

- Source:

which changed frequently in our period. Note that especially from the sixteenth century onward, the samples show a strong overlap in terms of the markets represented (Table 1). This facilitates the interpretation of the results of our analyses from a long-term perspective.

\section{RESULTS: CONVERGENCE AND CO-MOVEMENT}

As a first cut, Figure 1 documents the coefficient of variation for all the markets (unbalanced sample), including a polynomial trend for ease of exposition. Notwithstanding pronounced fluctuations in the short and medium term, the data suggest a long-run trend fall in price dispersion from, broadly, the first half of the fifteenth through to the early twentieth century. Note, though, there were significant -if temporary - reversals, especially in the early sixteenth and early seventeenth centuries as well as during the French Revolutionary and Napoleonic Wars. From about 1850 , price differentials remained more or less stable.

Figure 2 compares the pattern of convergence from 1450 onward according to the unbalanced and the long-run balanced sample. The latter always includes the same 15 markets. The overall picture of a long-run decline in price dispersion is broadly similar in both samples. However, there are striking differences in detail and timing: Despite some pronounced variation, price differentials within the balanced sample declined from a peak at the end of the fifteenth to a trough at the beginning of the seventeenth century. For the remainder of the early modern period, convergence 


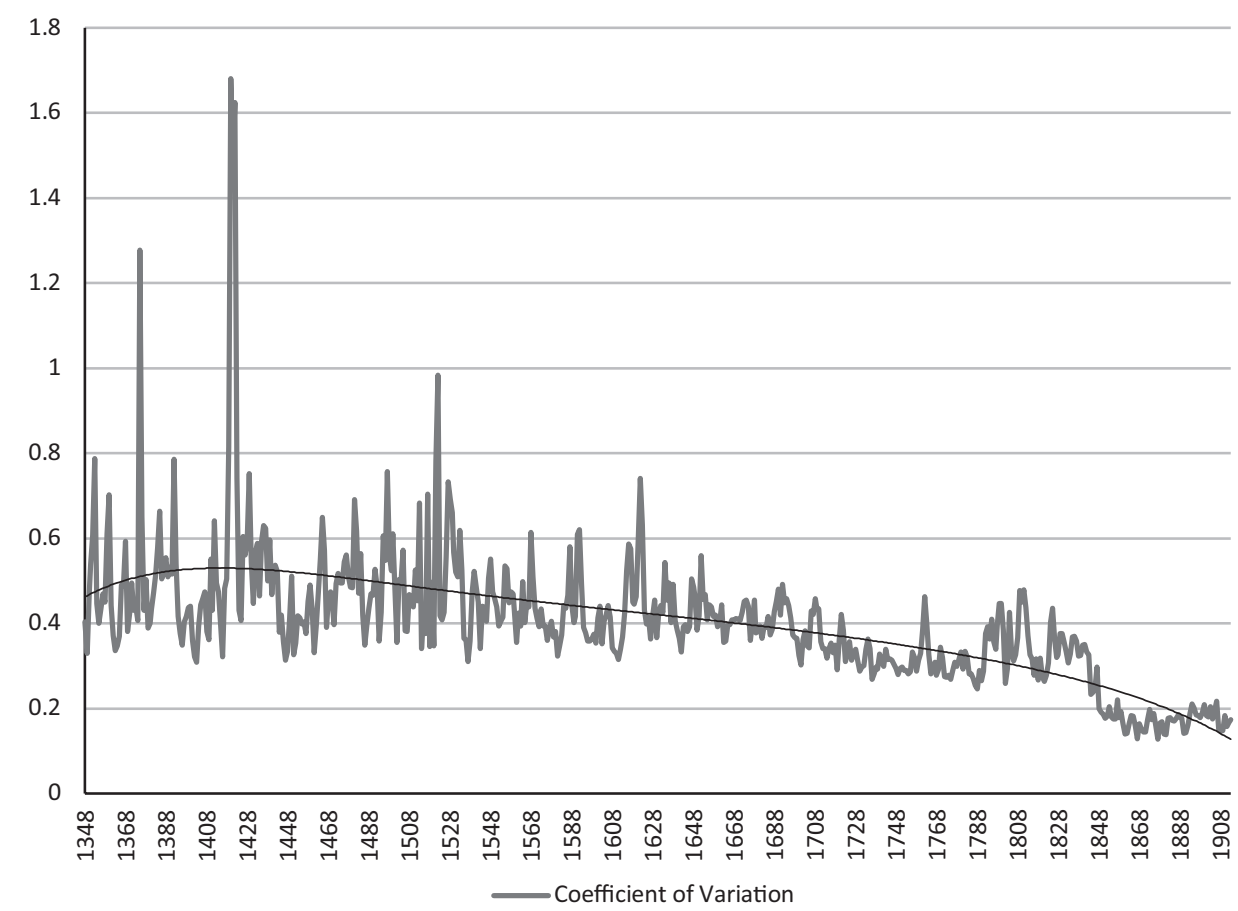

FIGURE 1

LONG-RUN PRICE CONVERGENCE-COEFFICIENT OF VARIATION, UNBALANCED SAMPLE

Source: See the text.

among the 15 markets did not progress beyond what had been achieved earlier on. The minimum of dispersion was reached in the 1870 s, with the decades thereafter seeing a major rollback in price convergence.

How valid is the impression gained from the development of the coefficient of variation of the balanced sample? We explore trend and level breaks more formally, using a Bai-Perron (2003) test. The results point to breaks in $1599,1649,1799,1842$, and 1875 , yielding six periods. For each of these periods, linear trends have been estimated with an error correction model (Razzaque et al. 2007):

$$
\Delta \ln \left(\mathrm{CV}_{t}\right)=c+\beta \text { TIME }+\psi \ln \left(\mathrm{CV}_{t-1}\right)+\varphi \Delta \ln \left(\mathrm{CV}_{t-1}\right)+u_{t},
$$

where TIME tests for the existence of a deterministic trend: prices converge if $\beta$ is negative and significant. The coefficient $\psi$ on the error correction term, which is expected to range between -1 and 0 , measures the speed of return to this trend: the higher $\psi$ is, the faster is the return to trend. The lagged shock term $\left[\Delta \ln \left(\mathrm{CV}_{t-1}\right)\right]$ is added to account for possible serial 


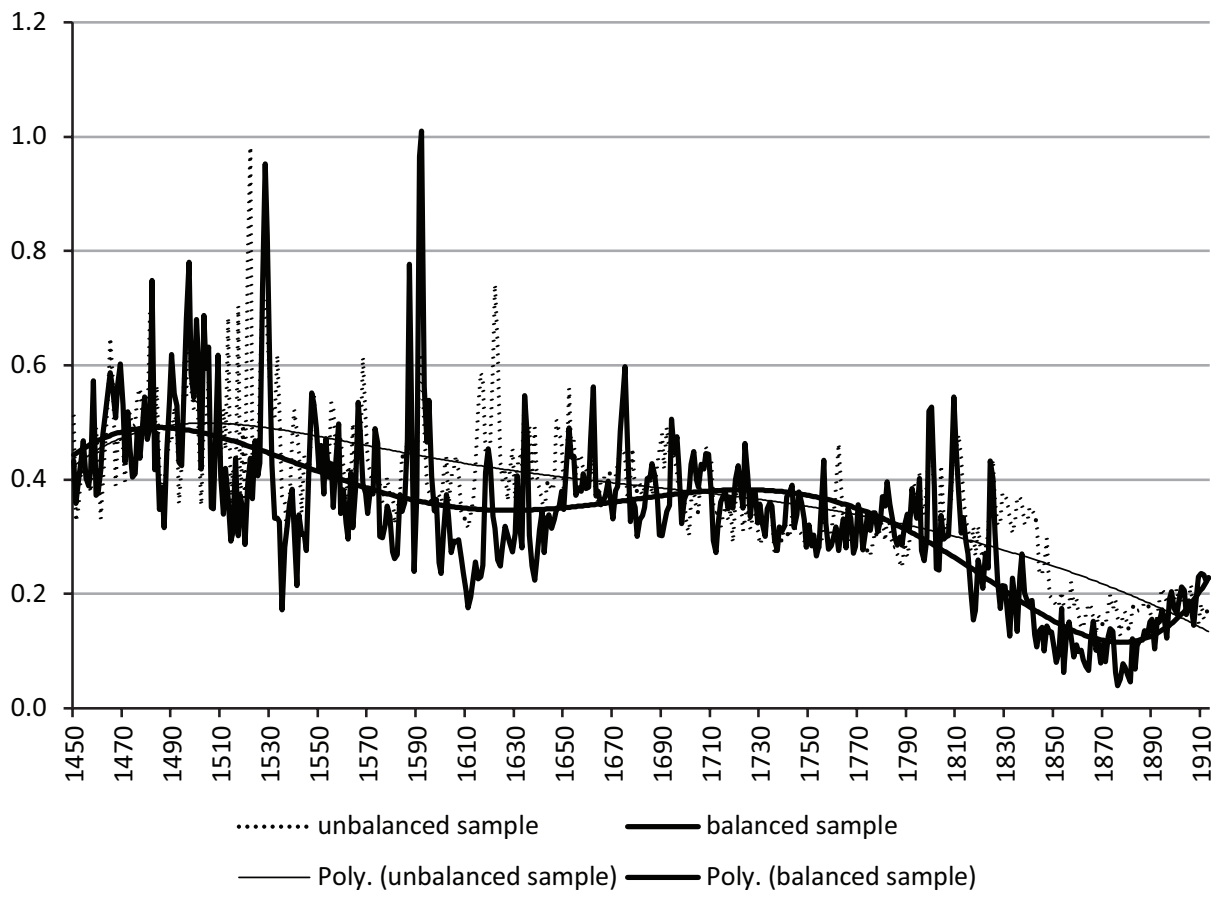

FIGURE 2

LONG-RUN PRICE CONVERGENCE-COMPARISON: UNBALANCED VERSUS BALANCED SAMPLE

Source: See the text.

correlation. We compute the trend rates rate of change as $t=-(\beta / \psi)$ and test the null hypothesis of the rates being zero with a Wald test.

The table offers three important insights: ${ }^{11}$ First, arguably the most striking result is the early onset of price convergence in the fifteenth

\footnotetext{
${ }^{11}$ Note that trends are estimated separately for each period. The implication is that there are (minor) differences in the estimated initial CV and the implied level resulting from accounting for the absolute change over the preceding period. The resulting discontinuity gaps between the trend values at the end of one period and the start of the next period are, however, not nearly large enough to make a material difference to the periodization of price convergence and divergence. This is confirmed by two basic robustness checks. First, for each period, we considered the cumulated and implied yearly changes incorporating the fitted values after the break (e.g., 1452-1599 instead of 1452-1598). While growth rates and absolute differences in the CV change, they are fully consistent with the initial periodization, that is, there is no change in direction. If anything, the results so derived strengthen the point made here, namely, that there was a significant fall in price dispersion up to the beginning of the seventeenth century and a stark increase during the half-century encompassing the Thirty Years War. Further, the results add support to the view that the first half of the nineteenth century, including the recovery from the effects of the Napoleonic Wars, was a period of marked convergence in prices. Second, we looked at the Hodrick-Prescott filtered series of the CV and measured rates of change over each of the Bai-Perron periods. The temporal pattern of increases and decreases in price dispersion, as documented in Table 2, is replicated. Details are available from the authors.
} 
TABLE 2

TRENDS IN THE COEFFICIENT OF VARIATION, LONG-RUN BALANCED SAMPLE (BAI-PERRON PERIODS)

\begin{tabular}{lccccc}
\hline \hline & $\begin{array}{c}\text { Annual Change } \\
(\times 100)\end{array}$ & $\begin{array}{c}\text { Number } \\
\text { Years }\end{array}$ & $\begin{array}{c}\text { Percentage } \\
\text { Change }\end{array}$ & $\begin{array}{c}\text { CV, Initial Year } \\
\text { (Fitted })\end{array}$ & $\begin{array}{c}\text { Absolute Change } \\
\text { CV }\end{array}$ \\
\hline $1452-1913$ & $-0.26^{* * *}$ & 462 & -70.19 & 0.56 & -0.39 \\
$1452-1598$ & $-0.18^{*}$ & 147 & -23.14 & 0.49 & -0.11 \\
$1599-1648$ & $0.52^{*}$ & 50 & 29.23 & 0.26 & 0.08 \\
$1649-1798$ & $-0.20^{* * *}$ & 150 & -26.06 & 0.41 & -0.11 \\
$1799-1841$ & $-1.87^{* * *}$ & 43 & -54.44 & 0.39 & -0.21 \\
$1842-1874$ & -0.54 & 33 & -15.98 & 0.12 & -0.02 \\
$1875-1913$ & $3.77^{* * *}$ & 39 & 318.31 & 0.07 & 0.21 \\
\hline
\end{tabular}

Wald test:

$*=$ Significant at the 10 percent level.

** = Significant at the 5 percent level.

$* * *$ Significant at the 1 percent level.

( Source:

century. By around 1600 , price dispersion had already reached a level lower than in the early nineteenth century (fifth column in Table 2). Of course, such gains depended on time and place specific circumstances and indeed they were reversed in the first half of the seventeenth century. However, and this is our second point, this divergence had no lasting impact as convergence resumed after the end of the Thirty Years' War. Thus, what Chilosi et al. (2013, p. 50) call "early roots" of integration, referring to the late seventeenth and early eighteenth centuries, was no more than an intermediate stage in a process that had begun at least 150 years before the start date of their analysis. Third, the table confirms that the first half of the nineteenth century, after the end of the French wars, was an age of rapid price convergence. However, this was reversed after 1870 .

A glance at Figures 1 and 2 suggests that the story told by the evidence from the complete, unbalanced sample differs from what the long-run balanced sample shows. This may be due to either the changing composition of the unbalanced sample, or its broader geographical coverage, or both (Maps 1 and 2). How representative, then, is the smaller long-run balanced sample?

We address this question in two ways. First, we consider to what extent the long-run balanced sample is representative of the area it covers, that is, markets between Southern England and Northern Italy. To this end, we draw on subsets of the seven period-specific balanced samples, which include only markets situated within the minimum-length geographical 
perimeter of the long-run sample (Map 2), and then compare the trends in the respective coefficients of variation. Second, we gauge the extent to which the long-run balanced sample is representative of the entire continent by contrasting trends in price dispersion in the former with the corresponding evidence extracted from the full set of period-specific balanced samples, which include markets from all over Europe (Table 1).

There are two alternative periodizations. The first is based on the 80 -year period-specific samples. The second uses the Bai-Perron break dates in the long-run balanced sample, which is compared to a composite (spliced) series of the period-specific balanced samples. While there is some change in the makeup of the composite series, there is a large degree of overlap in the composition of the period-specific samples incorporated (Table 1).

Table 3 reports the results. Comparison is facilitated by a Wald test of the null hypothesis of equal coefficients; "NR" indicates non-rejection of the hypothesis, implying that the rate of change of the coefficient of variation of the 80 -year period-specific sample equals that of the long-run sample, and " $R$ " that it is rejected.

The upper panel shows that the long-run balanced sample of 15 markets is representative of the rates of change in price dispersion pertaining to the much larger number of markets located within its geographical perimeter (Columns (1)-(3)). It also mirrors the direction of change apart from the periods 1450-1509 and 1581-1660. Using the same samples but Bai-Perron periodization (lower panel) confirms these findings. The only exceptions are the late nineteenth and early twentieth centuries, where the rates of change differ significantly but, crucially, not their direction-both samples show statistically significant divergence after 1874 . Over the entire period 1452-1913, the composite series of period-specific samples within the perimeter replicates the behavior of the balanced long-run sample. In contrast, the results for the full (or "pan-European") set of period-specific samples are markedly different from those for the balanced long-run sample (Columns (1), (4), and (5)).

These robustness checks suggest that the long-run balanced sample represents the patterns of price divergence and convergence in the area between Southern England and Northern Italy more accurately than those in the rest of the Continent. This warrants a closer look at the regional dimensions of integration. With the onset of the Little Divergence in about the early seventeenth century, the trajectories of the different European economies began to diverge markedly: Underpinned by their comparatively early development of modern institutions, England and the Dutch Republic expanded most rapidly and assumed economic leadership from 
TABLE 3

TRENDS IN THE COEFFICIENT OF VARIATION—COMPARISON OF LONG-RUN AND PERIOD-SPECIFIC BALANCED SAMPLES

\begin{tabular}{ccccccc}
\hline \hline & \multicolumn{2}{c}{$\begin{array}{c}\text { Period Specific } \\
\text { (Markets within } \\
\text { Perimeter Only) }\end{array}$} & & \multicolumn{2}{c}{$\begin{array}{c}\text { Period Specific } \\
\text { (All Markets } \\
\text { in Respective Samples) }\end{array}$} \\
\cline { 2 - 3 } $\begin{array}{c}\text { Long-Run } \\
\text { Balanced Rate } \\
\text { of Change }\end{array}$ & $\begin{array}{c}\text { Rate of } \\
\text { Change }\end{array}$ & $\begin{array}{c}\text { Equal Rates } \\
P \text {-Value }\end{array}$ & & $\begin{array}{c}\text { Rate of } \\
\text { Change }\end{array}$ & $\begin{array}{c}\text { Equal Rates } \\
P \text {-Value }\end{array}$ \\
\hline$(1)$ & $(2)$ & $(3)$ & & (4) & (5)
\end{tabular}

Overlapping 80-year periodization: all samples balanced

\begin{tabular}{llllllll}
\hline $1450-1509$ & 0.35 & -0.01 & 0.259 & $\mathrm{NR}$ & $0.10^{1}$ & 0.352 & $\mathrm{NR}$ \\
$1508-1587$ & -0.03 & -0.19 & 0.658 & $\mathrm{NR}$ & $-0.30^{* *}$ & 0.396 & $\mathrm{NR}$ \\
$1581-1660$ & -0.09 & 0.15 & 0.468 & $\mathrm{NR}$ & 0.06 & 0.615 & $\mathrm{NR}$ \\
$1644-1723$ & -0.06 & -0.14 & 0.622 & $\mathrm{NR}$ & $-0.36^{* * *}$ & 0.043 & $\mathrm{R}^{* *}$ \\
$1706-1785$ & $-0.23^{* * *}$ & $-0.26^{* * *}$ & 0.851 & $\mathrm{NR}$ & -0.16 & 0.586 & $\mathrm{NR}$ \\
$1772-1851$ & $-1.42^{* * *}$ & $-1.13^{* * *}$ & 0.435 & $\mathrm{NR}$ & -0.53 & 0.032 & $\mathrm{R} * *$ \\
$1834-1913$ & $0.75^{*}$ & 0.43 & 0.739 & $\mathrm{NR}$ & 0.15 & 0.430 & $\mathrm{NR}$ \\
\hline
\end{tabular}

Bai-Perron

Breaks: Balanced Composite Composite

\begin{tabular}{llllllll}
\hline $1452-1598$ & $-0.18^{*}$ & 0.01 & 0.115 & $\mathrm{NR}$ & $-0.18^{* *}$ & 0.984 & $\mathrm{NR}$ \\
$1599-1648$ & $0.52^{*}$ & $0.66^{*}$ & 0.775 & $\mathrm{NR}$ & 0.17 & 0.540 & $\mathrm{NR}$ \\
$1649-1798$ & $-0.20^{* * *}$ & $-0.13^{* * *}$ & 0.156 & $\mathrm{NR}$ & $-0.21^{* * *}$ & 0.967 & $\mathrm{NR}$ \\
$1799-1841$ & $-1.87^{* * *}$ & $-1.70^{* * *}$ & 0.705 & $\mathrm{NR}$ & -0.55 & 0.043 & $\mathrm{R} * *$ \\
$1842-1874$ & -0.54 & $-1.56^{* * *}$ & 0.080 & $\mathrm{R} *$ & $-1.42^{* * *}$ & 0.084 & $\mathrm{R}^{*}$ \\
$1875-1913$ & $3.77^{* * *}$ & $2.19^{* * *}$ & 0.019 & $\mathrm{R} * *$ & $1.18^{* * *}$ & 0.000 & $\mathrm{R}^{* * *}$ \\
$1452-1913$ & $-0.26^{* * *}$ & $-0.23^{* * *}$ & 0.551 & $\mathrm{NR}$ & $-0.18^{* * *}$ & 0.049 & $\mathrm{R}^{* *}$ \\
\hline
\end{tabular}

$*=$ Significant at the 10 percent level.

$* *$ Significant at the 5 percent level.

$* * *$ = Significant at the 1 percent level.

${ }^{1} 1430-1509$

(1) Source:

Northern Italy (Allen 2001; Fouquet and Broadberry 2015; de Pleijt and van Zanden 2016). To what extent did the Little Divergence coincide with more advanced market integration among the economic leaders?

We address the issue by defining six regional groups of markets broadly along polity boundaries as of $1649 .{ }^{12}$ The mid-seventeenth century has

\footnotetext{
${ }^{12}$ Polity or state borders, rather than, for example, endogenously identified regional clusters, are chosen here for the match with common practice in the historiography. However, political borders changed significantly over the period and using present-day boundaries as a means to impose intertemporal consistency makes little historical sense.
} 


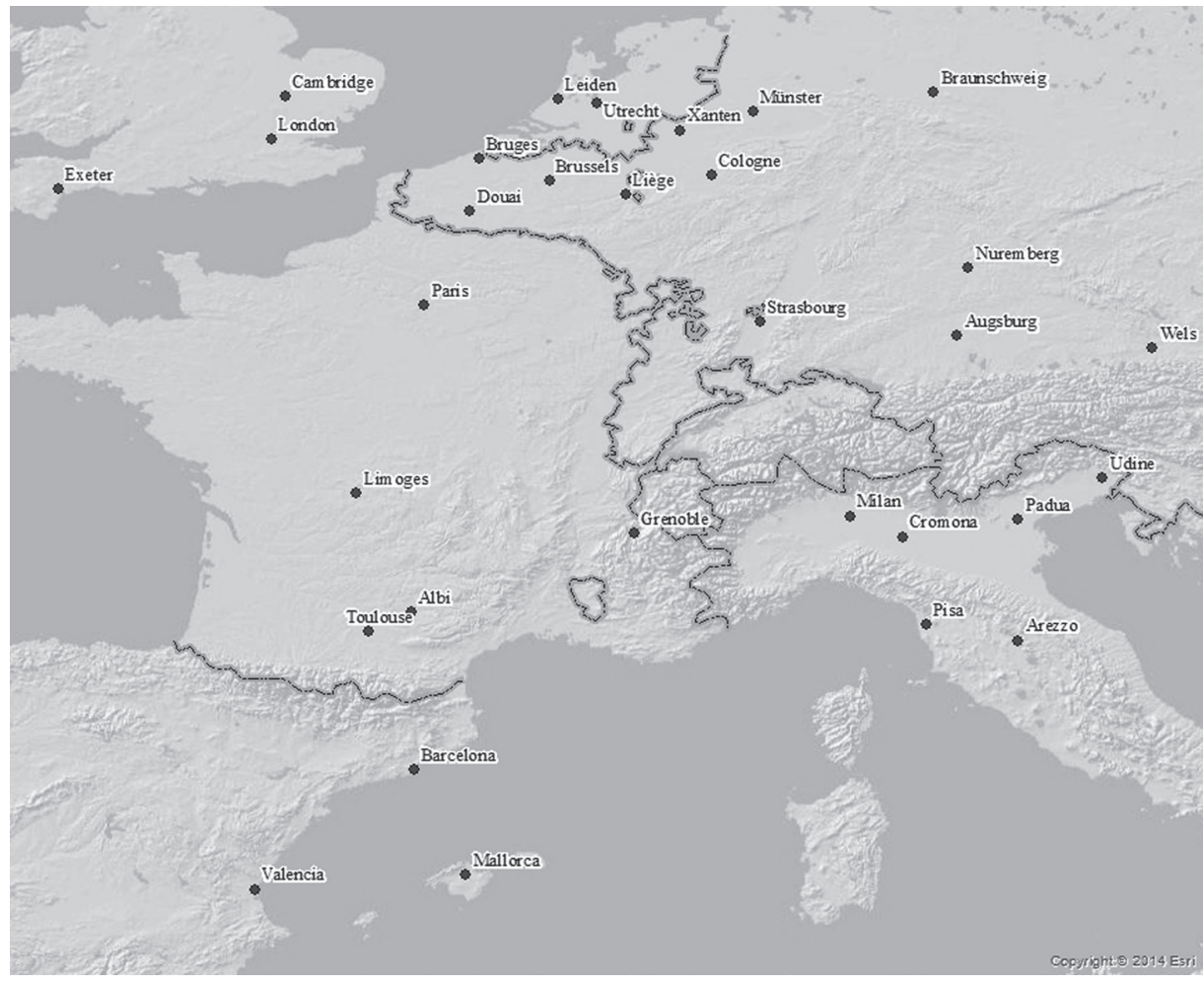

MAP 3

1508-1785 BALANCED SAMPLE: 31 MARKETS

Sources: Authors' own elaboration; underlying map: Esri. "World Light Grey Base" [basemap]. Scale Not Given. January 31, 2015

been chosen as it marks the center of the period studied; it also corresponds well with the timing of the Little Divergence and the end of the Thirty Years' War. The six "regions" are covered in both the long-run unbalanced sample and a balanced sample of 31 markets for 1508-1785 and include Britain (England/Scotland, which for most of our period were politically integrated to a smaller or larger extent), France, the Holy Roman Empire north of the Alps (i.e., those of its territories subject to the Imperial constitution (cf. Schmidt 2011, p. 46)), Italy, which was, in Metternich's words, a "geographical expression" rather than a political unit, the Dutch Republic, and the Iberian Peninsula (Map 3). ${ }^{13}$

The size of these regions differed and so did, ceteris paribus, average distance-related trade costs between markets in each area. Thus, levels

\footnotetext{
${ }^{13}$ In order to facilitate comparisons, the following discussion focuses on these six regions, though the more comprehensive unbalanced sample also includes markets from Eastern and Southeastern Europe, Scandinavia, and Switzerland.
} 
of integration and their changes over time have been measured by comparing actual gaps between all pairs of markets in each region with year-specific, distance-adjusted price gaps. First, we estimate the elasticity of price gaps with respect to distance, as a proxy for trade costs, by running the regression for all pairs of markets $i$ and $j$ in year $t$ :

$$
\operatorname{abs}\left(\ln \left(P_{i t} / P_{j t}\right)\right)=\varphi_{t} \ln \left(\operatorname{dist}_{i j}\right) \text {. }
$$

Second, as the coefficient is very volatile (because the cross section changes from year to year and there are strongly fluctuating prices), we smooth the yearly series of $\varphi$ with an Epanechnikov kernel and then compute the expected price gap for each pair of markets, given their distance. Third, we average the differences between actual and expected price gaps for the markets of each region in year $t$ and divide the result by the (smoothed) average of bilateral price gaps across European markets in the given year (minus one). ${ }^{14}$ There are two versions. Figure 3a uses as denominator all available market pairs in the long-run unbalanced sample, that is, it compares average distance-adjusted price gaps in the six regions with the average for the entire continent (cf. Map 1). Figure 3b, in contrast, draws only on price gaps between the markets in the balanced 1508-1785 sample, that is, it compares price gaps in any of the six regions with the average across these regions that make up the sample area (cf. Map 3). In both cases, a ratio below zero implies that markets within a given region are better integrated than the relevant European average.

A first look at the evidence from the broader, Europe-wide unbalanced sample (Figure 3a) indicates strong regional deviations from the average European price gap. Markets in France, the Holy Roman Empire, and Italy appear distinctly less well integrated than the average, while price gaps in Britain were consistently smaller. The position of the Dutch Republic and Iberia changed over time. In this context, the evidence on the Northern Netherlands ties in well with the idea of a Little Divergence beginning in the seventeenth century. However, Britain enjoyed an integration advantage over the rest of the continent throughout the period. ${ }^{15}$

The comparison within the area covering only the six regions (Figure 3b) shows that in the sixteenth century, English and Dutch markets were well integrated, but not exceptionally so. Price differentials between them were smaller than those between markets in France, Iberia, and

\footnotetext{
${ }^{14}$ The periodization corresponds with the Bai-Perron breakpoints estimated for the long-run balanced sample.

${ }^{15}$ This ties in well with Masschaele's (1993) finding that transport costs were already low in medieval England.
} 
3.0

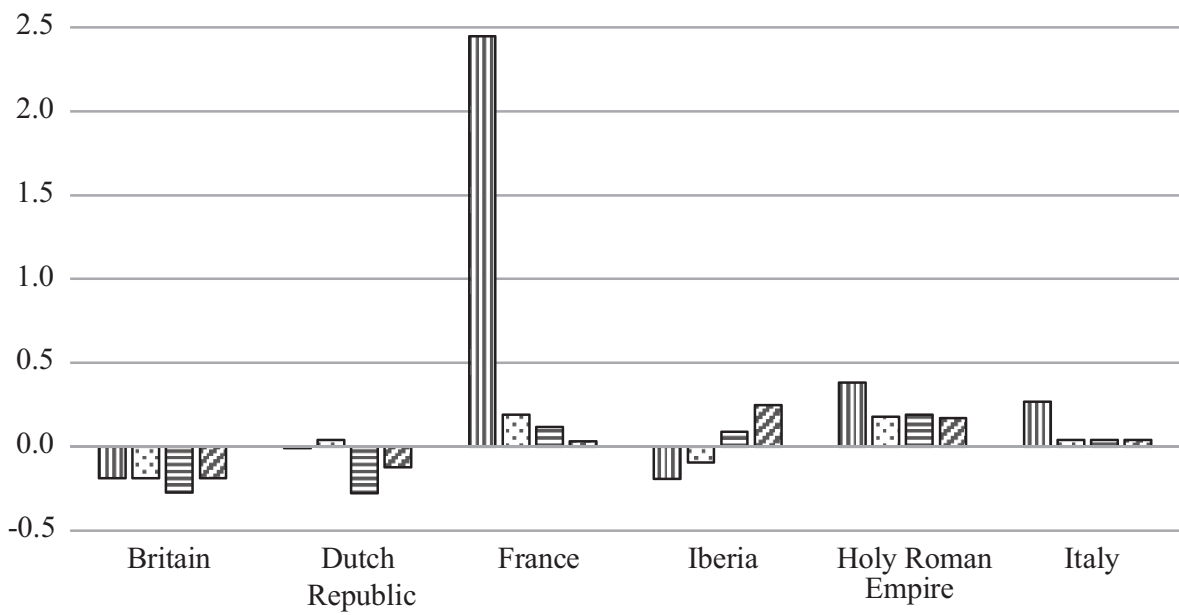

血 1348-1449 1450-1598 目 1599-1648 包 1649-1798

FIGURE 3A

AVERAGE DISTANCE-ADJUSTED PRICE GAPS BY REGION

(UNBALANCED SAMPLE), 1348-1798

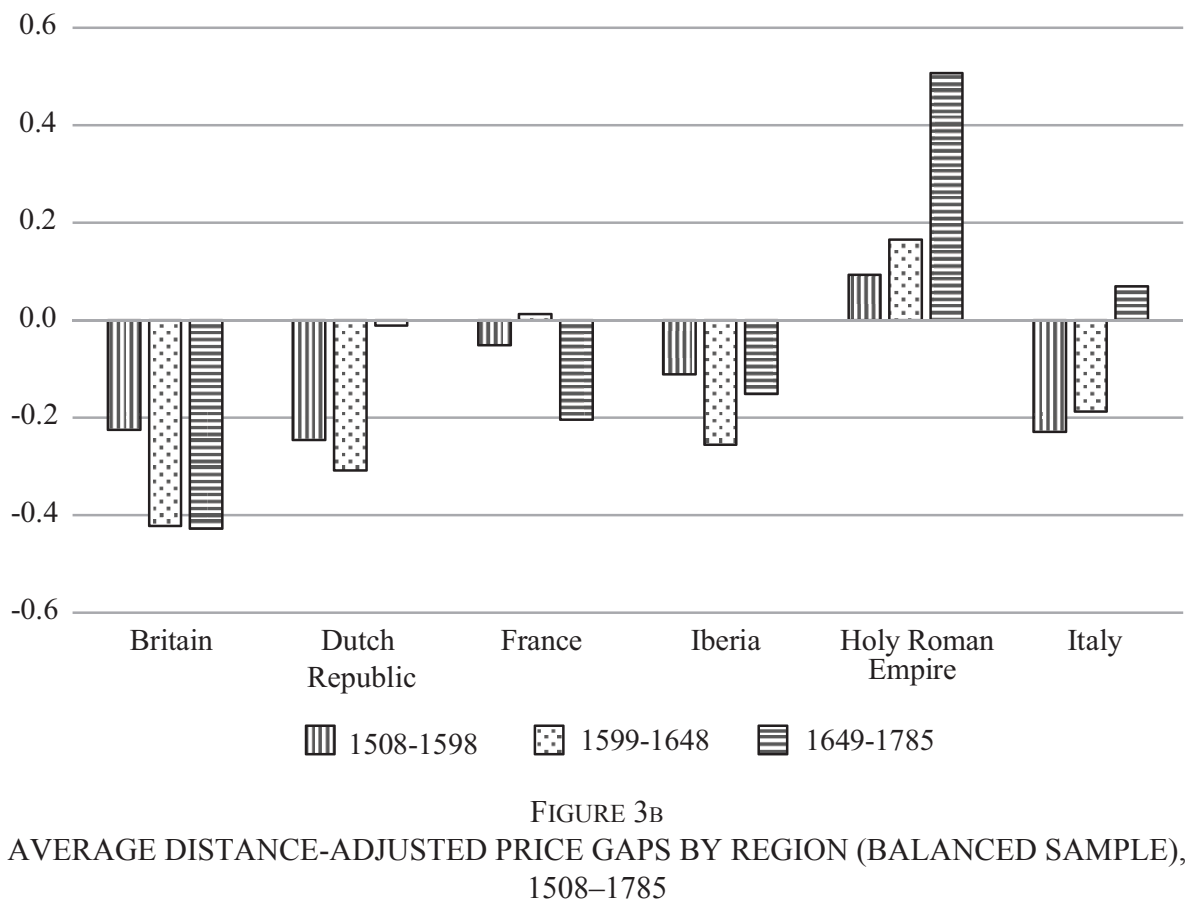

Source: See the text. 
most clearly the Empire, but Italian markets were still roughly on a par. From the early seventeenth century onward, however, Britain and the Netherlands became truly exceptional. The Empire and Italy, by contrast, deteriorated progressively in relative terms. Taken together, these findings lend considerable support to the claim that the Little Divergence began in the seventeenth century. The results for Iberia need to be taken with a pinch of salt: All three markets are on the coast, which made for comparatively easy communication between them.

While providing a comprehensive explanation of these findings is beyond the scope of this paper, offering a tentative hypothesis for future research is in order. Thus, the lack of internal custom borders, the easy access to water transport in most of the country, and the relative rarity of destructive warfare on the British Isles are likely to have contributed to the exceptionally rapid and far-reaching advance of price convergence between markets in England. The Dutch Republic cannot but have benefited from easy access to internal water transport. The Empire, by contrast, was ravaged in the Thirty Years' War, which, though being a Europe-wide conflict, was mainly fought on its territory. In addition, the war acted as an "institutional hothouse" (Ogilvie 1992/97): Governments attempted to cover the costs of warfare by selling regional monopoly rights that stayed in place long after the return of peace, tore apart existing trade links, and prevented the creation of new ones.

So far, the discussion of results has focused on price convergence as the first of two dimensions of market integration explored in this paper. Next, we turn to the second dimension, market efficiency, which we approximate by its outcome, that is, by the extent of co-movement in prices. The more efficient a market, the less likely are permanent equilibrium price differentials between different locations.

Here, we draw on DFA, as set out above, to derive a sample-wide (synthetic) measure of "efficiency" (in the Empirical Strategy section). Running the DFA model over rolling windows, we settle for 51-year rolls for the balanced long-run and the first period-specific sample (15 and 13 markets, respectively) and 25-year rolls for the other period-specific samples (between 32 and 116 markets). ${ }^{16}$ Each roll yields estimates of the

\footnotetext{
${ }^{16}$ The length of the period of each roll is determined by the need for a minimum number of total observations for a meaningful estimate. Given that the long-run sample includes only 15 markets (and the first period-specific sample only 13), as compared to the far larger number of markets included in the other period-specific samples, a longer run of 51 years gives a more appropriate number of observations. The use of rolls causes the loss of overlap between the different periodspecific samples, ruling out simple splicing or chain linking, hence the gaps. The DFA results for the period-specific samples have then been normalized on the long-run balanced sample on the basis of the first year in which they overlap. This is to avoid jumps in levels caused by changes in the composition of cities in the period-specific samples.
} 


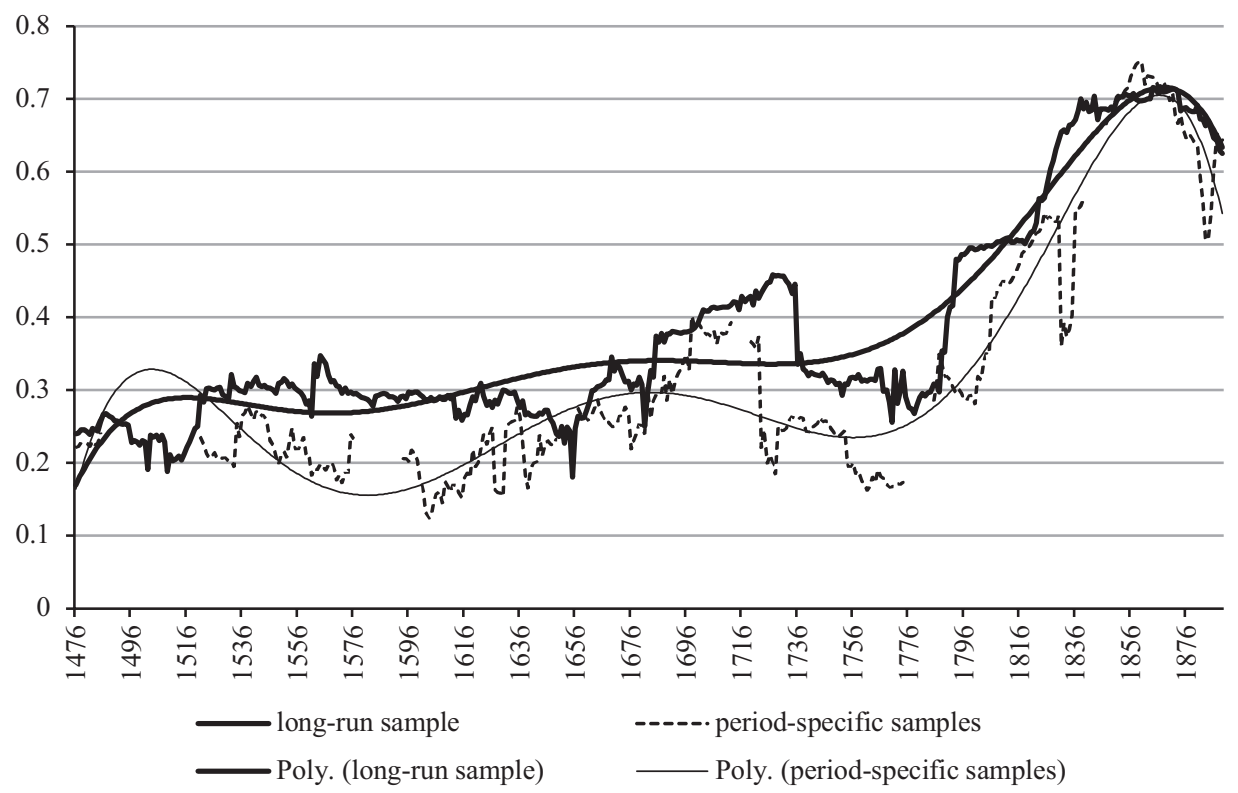

FIGURE 4

EFFICIENCY MEASURES, BALANCED SAMPLES

Source: See the text.

common factors $\left(c_{t}\right)$ and of market loadings $\left(\lambda_{i}\right)$-and, thus, of $\tau_{i}$ and $T_{i}$. These parameters refer to all years of the roll. For instance, the earliest roll of the long-run sample is computed with the years 1450-1501, and it measures the efficiency in 1476 , its $26^{\text {th }}$ year.

Both series suggest that market efficiency, as approximated by co-movement, grew over the long term, though with distinct level differences between the long-run and period-specific samples (Figure 4). Comparing the measures for both samples suggests that, taken together, the 15 markets included in the long-run balanced sample were more efficient for most of the period under review than the far larger number of markets in the period-specific samples. There are also some differences in the timing of short-run variations, but - and this is the main point - the trends suggest that the major phases of increase and decline in efficiency were fairly well aligned between the samples. Market efficiency started to improve slowly in the sixteenth century and, after a sharp reversal in the mid-eighteenth century, gains accelerated just before and after the French wars. ${ }^{17}$ Some of the potential causes of inter-temporal changes in efficiency are discussed in the next section.

${ }^{17}$ These DFA-based findings are supported by correlation-based measures of co-movement as a robustness check. Details are available from the authors. 


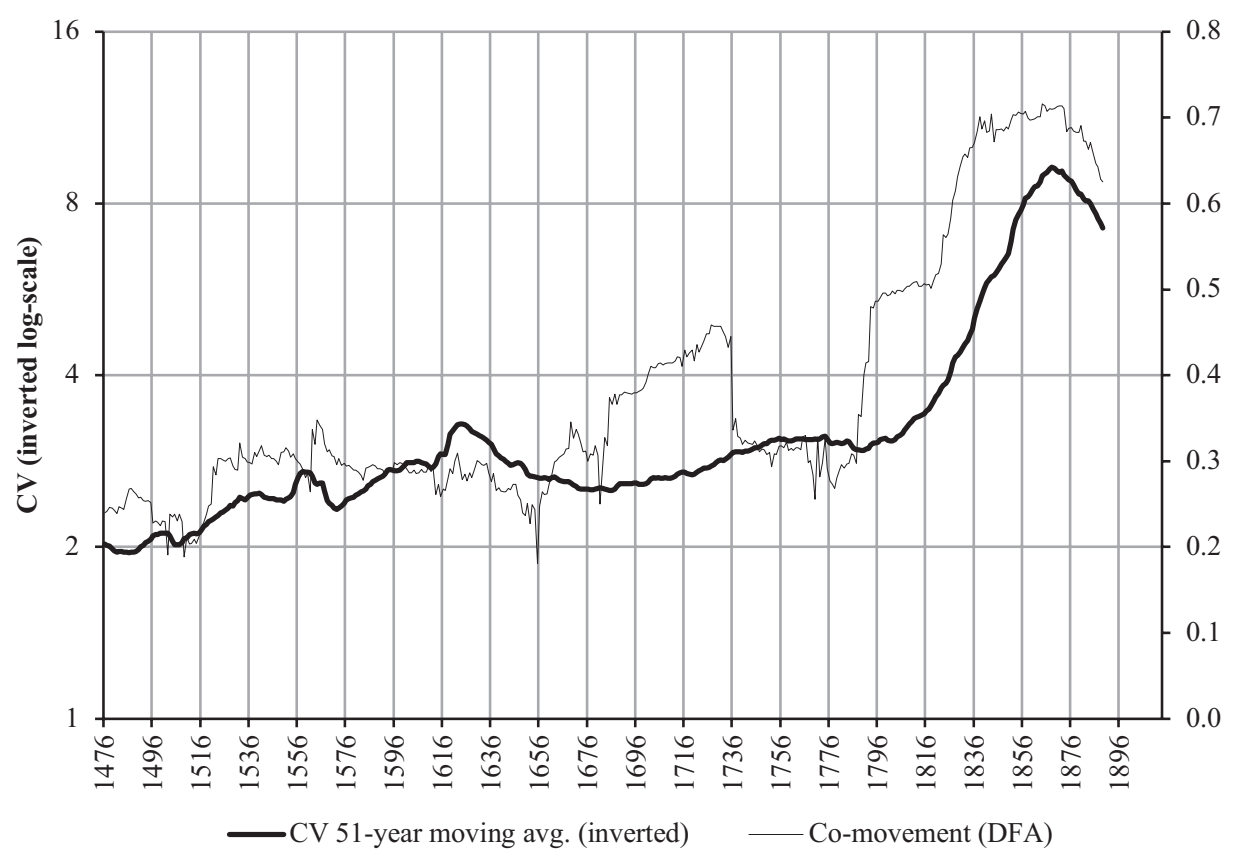

FIGURE 5

PRICE-CONVERGENCE AND CO-MOVEMENT—BALANCED LONG-RUN SAMPLE

Source: See the text.

\section{THE INTEGRATION OF THE EUROPEAN MARKET}

Figure 5 compares the main findings on price convergence and efficiency. The graph reproduces the DFA-based efficiency measure for the long-run sample from Figure 4. For ease of comparison, the series of the coefficient of variation (from Figure 2), expressed on a log scale, has been inverted and smoothed with a 51-year moving average.

In the long run, market integration improved along both its dimensions: prices converged and co-movement increased (or markets became more efficient). However, the pattern of changes differed significantly between the two measures over extended periods, that is, between c. 1560 and 1618, the years from about 1655 to the $1670 \mathrm{~s}$, and from the 1730 s to the 1770s. It was only in the first half of the sixteenth century, the Thirty Years' War period, and from about 1790 onward that price convergence and co-movement moved broadly in tandem.

Concerning co-movement, our findings differ markedly from Chilosi et al. (2013) whose focus on the shorter, post-1620 period does not allow identifying the long-term trend that becomes apparent when the fifteenth and sixteenth centuries are included in the analysis. They see the 
increase in co-movement from about the 1770s in the context of French physiocratic policies that "lifted restrictions on the export of grains from localities" while at the same time pointing to "stationary trading costs in the second half of the $18^{\text {th }}$ century" and lauding the "achievements of mercantilist policies of state formation" (Chilosi et al. 2013, p. 52). There are two problems with these claims. First, Turgot's French physiocratic experiment of domestic grain market liberalization lasted less than two years (from September 1774 to May 1776; Jones 2003, pp. 296, 300; Persson 1999, pp. 5-6, 142-43). It would seem unlikely to have had a strong effect on Europe over the period 1770-1850. Second, there is no a priori reason why a rise in co-movement should be "difficult to reconcile" with either falling or stationary trade costs, as the authors seem to suggest.

Both price convergence and co-movement depend ultimately on trade costs. Trade costs "include all costs incurred in getting a good to a final user other than the marginal cost of producing the good itself: transportation costs (both freight costs and time costs), policy barriers (tariffs and non-tariff barriers), information costs, contract enforcement costs, costs associated with the use of different currencies, legal and regulatory costs, and local distribution costs (wholesale and retail)" (Anderson and Wincoop 2004, p. 691 f.). Some changes in these costs affect both convergence and efficiency in the same way, while others have a differential impact.

Market integration would be enhanced by institutional change, which makes arbitrage between spatially distinct markets less costly (e.g., by increasing physical or legal security), by reduction of duties and by a decline in transportation costs (and vice versa). Such changes cause the commodity points to narrow and, ceteris paribus, foster convergence and reduce the scope for uncorrelated price movements. For instance, it is well known that the 1830 s and 1840 s featured wide-ranging liberalization of wheat imports in Europe - the abolition of the Corn Laws being the best-known instance (Federico 2012b). Until the 1870s, duties on wheat remained nil or negligible in all major European countries. In response to the "grain invasion" of Europe, most Continental countries started to protect wheat production from the late 1870s/early 1880s and increased duties in the 1890s. On the eve of the First World War, duties on wheat were about 30 percent in Italy, France, and Germany (Bacon and Schloemer 1940). Eight of the fifteen markets in our long-run balanced sample are located in these countries. The ratio between their average prices and those of the seven markets in free-trade countries (Belgium, Netherlands, and the United Kingdom) rose from 1.04 in $1874-1876$ to 
1.36 in 1911-1913. The cross-country component (reflecting international trade) accounts for 97 percent of the increase in overall variance in the long-run sample.

Conventional wisdom holds that nineteenth-century progress in transport technology - most notably the adoption of steam-helped integration (O'Rourke 1997; Findlay and O'Rourke 2007). However, our results suggest we should not overrate the effects of technical change in this period. For one thing, the beginning of the railway age in Europe coincided with the trend break that marks the end of significant price convergence (1842); for another, the fall in transport costs in the second half of the century was obviously insufficient to make up for the effects of the protectionism that proliferated in Europe from the late 1870s onward. As for the preindustrial period, it is not clear to what extent changes in transport costs affected price convergence. The limited available evidence (Masschaele 1993; Ballaux and Blonde 2018) seems to rule out any substantial decline in overland transport costs before the advent of systematic road building in eighteenth century England and France (Bogart 2005 and 2019) and early nineteenth century Germany (Uebele and Gallardo-Albarran 2015). Concerning sea transport, the jury is still out. British domestic freight costs, at least, fell sharply in the second half of the eighteenth century (Harley 1988). Menard (1991) argued that in the long term, freight rates were stable, whereas Van Zanden and Tielhof (2009) found an at least temporary decline in Baltic rates in the fifteenth and sixteenth centuries. Lucassen and Unger (2011) argue that labor productivity in shipping grew fast since the Middle Ages, which also points to a decline in freight costs.

Changes in other components of trade costs may affect price convergence and efficiency in different ways. ${ }^{18}$ Consider, for example, information, and here not only the costs, but also the kind of information acquired. If such costs decline and the information is about existing price differentials, the scope for arbitrage over space increases, resulting in both price convergence between markets and stronger co-movement. If, however, information costs decline and the information is about expected price changes, then the outcome is an increase in the scope for arbitrage over time: Merchants may, for example, react by stockpiling grain, expecting to sell it at a later date and for a higher price. Arbitrage over time, therefore, will affect co-movement but not necessarily price convergence. Importantly, if the speed of transmitting such information differs regionally-for example, access to relevant news improves everywhere but more quickly in some markets than in others-the result will be a decline in overall

\footnotetext{
${ }^{18}$ See Brunt and Cannon (2014) for a careful econometric analysis for England between 1770 and 1820 .
} 
co-movement. Relaxing institutional restrictions on stockpiling aimed at exploiting expected price changes (forestalling, in early modern parlance) earlier in some places than in others should have similar consequences.

These factors likely account for many of the ups and downs in co-movement we observe before the 1770s. While the introduction of printing with movable types from the mid-fifteenth century made information more accessible, the importance of this innovation should not be overrated in the present context. After all, the new technology affected mainly the storage of information, rather than its transmission between markets (cf. Dudley 1999, p. 601). Information transmission improved primarily through two channels: the emergence of postal systems from about 1500 and that of newspapers from c. 1600 onward. Older ways of transmitting information had relied on sending irregular messengers who were often couriers in the literal sense of the word and, therefore, slow (Volckart 2007). Postal systems, by contrast, were characterized by regular links between markets, increasing speed, and reliability - three features that resulted from the creation of relay "posts," where messengers could change horses, and from the opening of public messenger services to private consumers. The first such system was established between the Habsburg territories in the Netherlands, the Tyrol and Milan from 1490 onward, with private individuals being permitted to use the Imperial mail from 1516. While the postal network spread over the Holy Roman Empire, Habsburg, Italy, and Spain with a speed that historians have called a "communications revolution" (Behringer 2005, p. 43 f.; Behringer 2006, p. 121), France and England copied the system only from, respectively, 1603 and 1636 onward (Morteveille 2009; Lewins 1865, p. 38 f.). ${ }^{19}$

The first modern newspaper - a weekly — appeared in Strasbourg in 1605 (Weber 1992, 2005). By stimulating interest in political news, the Thirty Years' War helped rather than hindered the spread of the new medium across the Empire, with the first daily paper appearing in its immediate aftermath in Leipzig. As Germany was politically decentralized, effective censorship was not feasible and almost any fact and opinion could be printed somewhere. The Empire was, therefore, a particularly propitious environment for the emergence of a wide reading public that enjoyed access to a variety of news from many places. By the end of the seventeenth century, about 200 different newspapers appeared in more than 70 of its towns and cities (Schröder 1995, p. 6 f.). In England, the licensing act that restricted publications lapsed in 1694, and from then onward, newspapers began to proliferate. The first daily appeared in London in 1702,

\footnotetext{
${ }^{19}$ For changes in postage costs in the eighteenth century, see Vinnal (2018).
} 
and in the provinces, 22 papers were founded between 1714 and 1725 alone. By 1780, there were 50 (Williams 2009, p. 49). Absolutist France, by contrast, had just one paper - the Gazette de France - that was allowed to publish political news, though between 1745 and 1785, the number of permitted foreign political papers increased from 5 to 19 (Censer 2002, pp. 8, 10). In short, the differential timing in the introduction of the new print medium across Europe is a likely part of the explanation as to why co-movement across European markets declined in the first half of the seventeenth century and increased thereafter up to the 1730s.

The ban on forestalling had restricted the ability of merchants to react to shocks that affected large numbers of markets simultaneously. Here, too, changes appeared in different regions at different times. Sreenivasan (2004, pp. 96, 271) has shown that whereas in South Germany traditional norms were still enforced in the fifteenth century, non-compliance spread and by the beginning of the seventeenth century the ancient ban on forestalling was a dead letter. In many English counties, by contrast, magistrates were still strictly enforcing such rules during the period of poor harvests in the mid-seventeenth century (Hindle 2008, pp. 74-76).

In sum, both the access of merchants to information and their freedom to respond to this information developed unevenly across space and time. Agents located in regions with no effective censorship, a variety of news channels, and institutions that imposed only weak restrictions on arbitrage over time were able to react quickly, while others were still lagging behind. It, thus, seems plausible that the observed decline in market efficiency in the middle decades of the eighteenth century was, to some extent, the result of the simultaneous spread of newspapers in the Holy Roman Empire and Great Britain and increasingly strict censorship in France during and after the Seven Years' War (the number of royal censors grew from 79 in 1741 to nearly 200 in 1789; Jones 2003, p. 116). However, price convergence and the underlying arbitrage over space were affected by different factors that could be triggered by the same historical events or processes. Wars, for example, stimulated the interest in news that might concern the expected supply of grain, creating opportunities for arbitrage over time. On the other hand, it is highly likely that war disrupted trade networks and had harmful effects on price convergence. Military operations, fear and uncertainty, and the requisitioning of draught animals were bound to disrupt commerce (Wilson 2010, p. 800). In the seventeenth century, for example, armies needed about 10 horses for every 15 soldiers (van Crefeld 2004, p. 24). At the height of the Thirty Years' War in Germany in 1631/32, Wallenstein and Gustavus Adolphus fielded around 100,000 men each (Wilson 2010, p. 494). These 


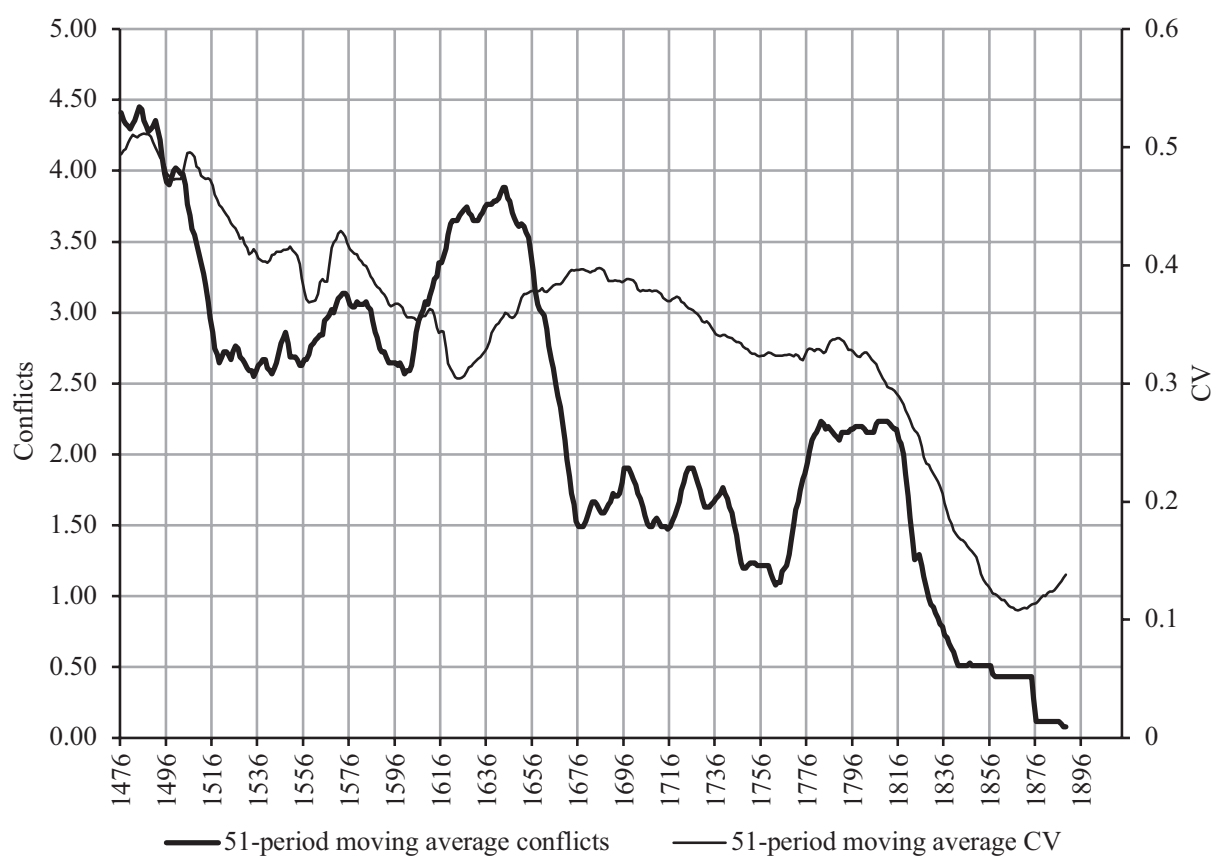

FIGURE 6

CONFLICTS AND CONVERGENCE

Sources: See the text. Data on conflicts from https://brecke.inta.gatech.edu/research/conflict/.

masses of troops would be accompanied by altogether at least 130,000 horses. According to Sombart's estimate (Sombart 1916/87, p. 341), just before the advent of the railway in the early nineteenth century, the entire transport sector of the German economy employed fewer than 40,000 horses. Even considering that many more were used in agriculture (in about 1800, approximately 2.7 million; Bittermann 1956, p. 42 f.), and that water transport played a large role, military requisitioning must have had a severe impact on commerce. The available data are consistent with the view that wars played a role in shaping the European pattern of price convergence and divergence between the fifteenth and early twentieth centuries. Drawing on Peter Brecke's data set, ${ }^{20}$ we computed the annual number of armed conflicts fought on the European territories covered in the long-run balanced sample. ${ }^{21}$ Across Europe, the average number of conflicts declined over the long term, imperfectly mirroring the fall in average price differentials. Figure 6 shows a fairly close association

\footnotetext{
${ }^{20}$ Conflict catalog available at https://brecke.inta.gatech.edu/research/conflict/.

${ }^{21}$ Note that we do not include wars fought by European countries outside of Europe; further, we do not include fatalities as a measure of the intensity of conflicts as the available data are extremely uneven.
} 
between the frequency of warfare and the level of the coefficient of variation, drawing on 51-year moving averages as in Figure 5. Simply put, on average and over the long term, war was positively correlated with an increase in price dispersion.

\section{CONCLUSION}

This paper examines two dimensions of integration of the European market for wheat - the convergence in prices and the increase in efficiency - over the period from the Black Death to the First World War. Geographically, this study covers most of Europe from the Atlantic to the Ural and from the White Sea to the Mediterranean.

Our results are based on data far more comprehensive across time and space than those used in earlier analyses. They suggest a distinctly different picture of the long-run process of price convergence from that drawn in the recent historiography. Convergence started in the late fifteenth century, advanced rapidly until the beginning of the seventeenth century when it temporarily stalled, resumed after the Thirty Years' War, and accelerated after the Napoleonic Wars in response to trade liberalization. From the late 1840 s, convergence petered out and turned into divergence after 1875 as policy decisions dominated technological change. Thus, grain market integration in Europe was in the main a pre-industrial phenomenon.

The results of our regional analysis of price gaps lend support to the notion of the Little Divergence between a rapidly advancing Northwest and the rest of the Continent beginning in the seventeenth century. However, a qualifier is required here: England enjoyed a significant integration advantage over the other European economies from as early as the fourteenth century. In the sixteenth century, both English and Dutch markets were better integrated than their counterparts but not by a large margin. It was from the early seventeenth century onward that these two economies became exceptionally well integrated as especially the Holy Roman Empire at the other end of the spectrum, but also Italy, deteriorated progressively in relative terms.

Long-term improvements in market efficiency, as signaled by co-movement, began in the early sixteenth century, that is, a few decades later than the onset of long-run price convergence. There were some temporary setbacks, notably in the second half of the sixteenth and in the mid-eighteenth century. The patterns of price convergence and co-movement overlap only weakly and in a few periods. This is likely the consequence of uneven institutional change and the non-synchronous spread 
of modern media and systems of information transmission that affected differentially the ability of merchants to react to news. Advances that were more rapid in some markets than in others would allow merchants in favored localities to react quickly, while others lagged behind. As a result, overall co-movement declined in such phases of development. It was only the comprehensive adoption of new media and information transmission systems as well as the eventual continent-wide erosion of traditional institutions restricting arbitrage over time in the late eighteenth century that initiated a period when price convergence and co-movement advanced in tandem.

These results have some implications for our interpretation of preindustrial economic history and, thus, for future research. First, the early modern period of European history emerges as the great age of commercial intensification at the continent-wide level. The impact of industrialization, railway construction, and trade liberalization in the nineteenth century was sizeable, but it cannot possibly explain the extent and temporal pattern of price convergence since 1450 observed here. Second, a fuller account of the regional dimensions of European market integration and the Little Divergence will have to address explicitly the causes of England's exceptionalism in the late Middle Ages. Finally, price convergence and improvements in market efficiency were frequently out of phase. We hypothesize that this had to do with differences in the timing and extent of changes in the costs of information relevant for arbitrage over space and the costs of information relevant for arbitrage over time. Testing this proposition empirically requires operationalizing transaction costs in a way that has rarely been attempted before (cf. Volckart 2007).

\section{REFERENCES}

Achilles, Walter. "Getreidepreise und Getreidehandelsbeziehungen europäischer Räume im 16. und 17. Jahrhundert." Zeitschrift für Agrargeschichte und Agrarsoziologie 7 (1959): 32-55.

Albers, Hakon, Ulrich Pfister, and Martine Uebele. "The Great Moderation of Grain Price Volatility: Market Integration vs. Climate Change, Germany, 1650-1790.” Mimeo 2018.

Allen, Robert C. "The Great Divergence in European Wages and Prices from the Middle Ages to the First World War." Explorations in Economic History 38, no. 4 (2001): 411-47.

Allen, Robert C., and Richard W. Unger. "The Depth and Breadth of the Market for Polish Grain 1500-1800." In Baltic Affairs Relations between the Netherlands and North-Eastern Europe 1500-1800, edited by Jacques P. S. Lemmink and J. S. A. M. van Koningsbrugge, 1-18. Nijmegen: Institute of Northern and Eastern European Studies, 1990. 
Anderson, James E., and Eric van Wincoop. "Trade Costs." Journal of Economic Literature 42, no. 3 (2004): 691-751.

Anonymous. "Ein hundert und fünf und dreyßigjähriger Auszug des mittleren GetraidePreisses der Churstadt Wittenberg, nach dem Stadtmaaße gerechnet." Gnädigst privilegirtes Leipziger Intelligenz-Blatt (1765): 301-304.

Bacon, L. B., and F. C. Schloemer. World Trade in Agricultural Products. Its Growth, Its Crisis, and the New Trade Policies. Rome: International Institute of Agriculture Rome, 1940.

Bai, Jushan, and Pierre Perron. "Computation and Analysis of Multiple Structural Change Models." Journal of Applied Econometrics 18, no. 1 (2003): 1-22.

Ballaux, Bart, and Bruno Blonde. "Road Transport Productivity in the Sixteenth Century Low Countries: The Case of Brabant, 1450-1650." Economic History Review 71, no. 3 (2018): 707-26.

Bateman, Victoria N. "The Evolution of Markets in Early Modern Europe, 1350-1800: A Study of Wheat Prices." Economic History Review 64, no. 2 (2011): 1-25.

- Markets and Growth in Early Modern Europe. London: Pickering and Chatto, 2012.

Behringer, Wolfgang. "'Von der Gutenberg-Galaxis zur Taxis-Galaxis'. Die Kommunikationsrevolution: Ein Konzept zum besseren Verständnis der Frühen Neuzeit." Historische Zeitschrift. Beihefte 41 (2005): 39-54.

__. "Kaiser, Reichstag und Postwesen (1490-1615)." In Der Reichstag 1486-1613: Kommunikation, Wahrnehmung, Öffentlichkeit, edited by Maximilian Lanzinner and Arno Strohmeyer, 117-48. Göttingen: Vandenhoeck \& Ruprecht, 2006.

Brecke, Peter. Conflict Catalog, https://brecke.inta.gatech.edu/research/conflict/

Bittermann, E. Die landwirtschaftliche Produktion in Deutschland 1800-1950: Ein methodischer Beitrag zur Ermittlung der Veränderungen des Umfanges der landwirtschaftlichen Produktion und der Ertragssteigerungen in den letzten 150 Jahren. Halle-Wittenberg, Germany: Faculty of Agriculture, Martin Luther University, 1956.

Bogart, Dan. 'Turnpike Trusts and the Transportation Revolution in $18^{\text {th }}$ Century England." Explorations in Economic History 42 (2005): 479-508.

. "Clio on Speed: A Survey of Economic History Research on Transport." In Handbook of Cliometrics, edited by Claude Diebolt and Michael Haupert. $2^{\text {nd }}$ edition, 1453-1478. Berlin, Heidelberg: Springer, 2019.

Broadberry, Stephen, Bruce M. S. Campbell, Alexander Klein, Mark Overton, and Baas van Leeuwen. British Economic Growth 1270-1870. Cambridge, UK: Cambridge University Press, 2015.

Brüggemann, Ludwig W. Beiträge zu der ausfürlichen Beschreibung des Königl. Preußischen Herzogthums Vor- und Hinter-Pommern, vol. 1. Stettin: Johann Samuel Leich, 1800.

Brunt, Liam, and Edmund Cannon. "Measuring Integration in the English Wheat Market, 1770-1820: New Methods, New Answers." Explorations in Economic History 52 (2014): 111-30.

Censer, Jack. The French Press in the Age of Enlightenment. London: Routledge, 2002.

Chevet, Jean-Michel. "National and Regional Corn Markets in France from the Sixteenth to the Nineteenth Century." Journal of European Economic History 25, no. 3 (1996): 681-703. 
Chevet, Jean-Michel, and P. Saint Amour. "L’integration des marchés du ble en France au XIXe siècle." Histoire et mesure 6, no. 1 (1991): 93-119.

Chilosi, David, Tommy E. Murphy, Roman Studer, and A. Coşkun Tunçer. "Europe’s Many Integrations: Geography and Grain Markets, 1620-1913." Explorations in Economic History 50, no. 1 (2013): 46-68.

Chilosi, David, and Oliver Volckart. "Money, States and Empire: Financial Integration and Institutional Change in Central Europe, 1400-1520." Journal of Economic History 71, no. 3 (2011): 762-791.

Clark, Gregory. A Farewell to Alms: A Brief Economic History of the World. Princeton, NJ: Princeton University Press, 2007.

de Pleijt, Alexandra M., and Jan Luiten van Zanden. "Accounting for the 'Little Divergence': What Drove Economic Growth in Pre-Industrial Europe, 1300 1800?" European Review of Economic History 20, no. 4 (2016): 387-409.

Dudley, Leonard. "Communications and Economic Growth." European Economic Review 43, no. 3 (1999): 595-619.

Epstein, Stephan R. Freedom and Growth: The Rise of States and Markets in Europe, 1300-1750. London and New York: Routledge, 2000.

Esri. "World Light Grey Base" [basemap]. Scale Not Given. January 31, 2015. http:// www.arcgis.com/home/item.html?id=ed712cb1db3e4bae9e85329040fb9a49 (November 12, 2020).

Federico, Giovanni. "When Did the European Market Integrate?" European Review of Economic History 15, no. 1 (2011): 93-126.

—. "How Much Do We Know about Market Integration in Europe?" Economic History Review 65, no. 2 (2012a): 470-97.

. "The Corn Laws in Continental Perspective." European Review of Economic History 16, no. 2 (2012b): 166-87.

. "Market Integration." In Handbook of Cliometrics, edited by Claude Diebolt and Mike Haupert, 633-58. $2^{\text {nd }}$ ed. Berlin-Heidelberg: Springer, 2019.

Federico, Giovanni, and Karl Gunnar Persson. "Market Integration and Convergence in the World Wheat Market, 1800-2000." In The New Comparative Economic History: Essays in Honor of Jeffrey G. Williamson, edited by Timothy J. Hatton, Kevin O'Rourke, and Alan M. Taylor, 87-113. Cambridge, MA and London: The MIT Press, 2007

3 Federico, Giovanni, Max-Stephan Schulze, and Oliver Volckart. "Replication: European Goods Market Integration in the Very Long Run: From the Black Death to the First World War." Ann Arbor, MI: Inter-university Consortium for Political and Social Research [distributor], 2020-XX-XX. https://doi.org/10.3886/XXXXXXXXX.

Findlay, Ronald and Kevin H. O'Rourke. Power and Plenty: Trade, War, and the World Economy in the Second Millennium. Princeton, NJ: Princeton University Press, 2007.

Fouquet, Roger, and Stephen Broadberry. "Seven Centuries of European Economic Growth and Decline." Journal of Economic Perspectives 29, no. 4 (2015): 227-44.

Froot, Kenneth A., Michael Kim, and Kenneth Rogoff. "The Law of One Price over 700 Years.” NBER Working Paper No. 5132, Cambridge, MA, 1995.

Gerhard, Hans-Jürgen, and Karl Heinrich Kaufhold. Preise im vor- und frühindustriellen Deutschland. Göttingen Schwartz, 1990.

3 AU: When you upload your replication files we can complete the citation. 
Gómez, Victor, and Agustin Maravall. "Programs TRAMO (Time Series Regression with Arima Noise, Missing Observations, and Outliers) and SEATS (Signal Extraction in Arima Time Series). Instructions for the User." Servicio de Estudios. Banco de España Working Paper No. 9628, Madrid, Spain, 1996.

Harley, Charles K. "Ocean Freight Rates and Productivity, 1740-1913: The Primacy of Mechanical Invention Reaffirmed.” Journal of Economic History 48, no. 4 (1988): 851-76.

Hindle, Steve. "Dearth and the English Revolution: The Harvest Crisis of 1647-50." Economic History Review 71, no. S1 (2008): 64-98.

Jacks, David S. "Market Integration in the North and Baltic Seas, 1500-1800." Journal of European Economic History 33, no. 3 (2004): 285-329.

. "Intra- and International Commodity Market Integration in the Atlantic Economy, 1800-1913." Explorations in Economic History 42, no. 3 (2005): 381-413.

Jones, Colin. The Great Nation: France from Louis XV to Napoleon. London: Penguin, 2003.

Kelly, Morgan. "The Dynamics of Smithian Growth." Quarterly Journal of Economics 112, no. 3 (1997): 939-64.

Kose, M. Ayhan, Christopher Otrok, and Charles H. Whiteman. "International Business Cycles: World, Region, and Country-Specific Factors." American Economic Review 93, no. 4 (2003): 1216-39.

Lewins, William. Her Majesty's Mails: A History of the Post-Office, and an Industrial Account of Its Present Condition. London: Sampson Low, 1865.

Lucassen, Jan, and Richard Unger. "Shipping, Productivity and Economic Growth." In Shipping and Economic Growth 1350-1850, edited by Jan Lucassen and Richard Unger, 1-44. Leiden: Brill, 2011.

Malanima, Paolo. Pre-Modern European Economy: One Thousand Years $\left(10^{\text {th }}-19^{\text {th }}\right.$ Centuries). Leiden: Brill, 2009.

Masschaele, James. "Transport Costs in Medieval England." Economic History Review 46, no. 2 (1993): 266-79.

Menard, Claude. "Transport Costs and Long-Range Trade, 1300-1800: Was There a European 'Transport Revolution' in the Early Modern Era?" In The Political Economy of Merchant Empires: State Power and World Trade, 1350-1750, edited by James D. Tracy, 228-75. Cambridge, UK and New York: Cambridge University Press, 1991.

Morteveille, Gérard. Guillaume Fouquet de la Varenne, Ministre de Henri IV, Surintendant général des Postes. Bonchamp: Imprim'services, 2009.

Ogilvie, Sheilagh. "Germany and the Seventeenth-Century Crisis." In The General Crisis of the Seventeenth Century, edited by Geoffrey Parker and Lesley M. Smith, 57-86. London and New York: Routledge, 1992/97.

O'Grada, Cormac, and Jean-Michel Chevet. "Famine and Market in Ancien Régime France." Journal of Economic History 62, no. 3 (2002): 706-33.

O’Rourke, Kevin H. “The European Grain Invasion 1870-1913.” Journal of Economic History 57, no. 4 (1997): 775-801.

Özmucur, Süleyman, and Şevket Pamuk. "Did European Commodity Prices Converge during 1500-1800?" In The New Comparative Economic History: Essays in Honor of Jeffrey G. Williamson, edited by Timothy J. Hatton, Kevin O'Rourke, and Alan M. Taylor, 59-85. Cambridge, MA and London: The MIT Press, 2007. 
Persson, Karl Gunnar. Grain Markets in Europe 1500-1900. Cambridge, UK: Cambridge University Press, 1999.

- An Economic History of Europe: Knowledge, Institutions and Growth, 600 to the Present. Cambridge, UK: Cambridge University Press, 2010.

Ravallion, Martin. Markets and Famines. Oxford: Clarendon Press, 1987.

Ravn, Morten O., and Harald Uhlig. "On Adjusting the Hodrick-Prescott Filter for the Frequency of Observations." Review of Economics and Statistics, 84, no. 2 (2002): 371-80.

Razzaque, Mohammed A., Philip Osafa-Kwaako, and Roman Grynberg. "Long-Run Trend in the Relative Price: Empirical Estimation for Individual Commodities." In Commodity Prices and Development, edited by Roman Grynberg and Samantha Newton, 35-67. Oxford: Oxford University Press, 2007.

Roehner, Bertrand M. Theory of Markets: Trade and Space-Time Patterns of Price Fluctuations. A Study in Analytical Economics. Berlin: Springer, 1994.

Schmidt, Georg. "The State and Nation of the Germans." In The Holy Roman Empire: 1495-1806, edited by Robert J. W. Evans, Michael Schaich, and Peter H. Wilson, 43-62. Oxford: Oxford University Press, 2011.

Schröder, Thomas. Die ersten Zeitungen: Textgestaltung und Nachrichtenauswahl. Tübingen: G. Narr, 1995.

Sombart, Werner. Der moderne Kapitalismus: Historisch-systematische Darstellung des gesamteuropäischen Wirtschaftslebens von seinen Anfängen bis zur Gegenwart, Vol. 1: Die vorkapitalistische Wirtschaft, Halbbd. München: DTV, 1916/87.

Sreenivasan, Govind. The Peasants of Ottobeuren, 1487-1726: A Rural Society in Early Modern Europe. Cambridge, UK: Cambridge University Press, 2004.

Studer, Roman. The Great Divergence Reconsidered: Europe, India and the Rise to Global Economic Power. Cambridge, UK: Cambridge University Press, 2015.

Taylor, Alan. "Potential Pitfalls for the Purchasing-Power-Parity Puzzle? Sampling and Specification Biases in Mean-Reversion Tests of the Law of One Price." Econometrica 69, no. 2 (2001): 473-98.

Tilly, Louise A. "The Food Riot as a Form of Political Conflict in France." Journal of Interdisciplinary History 2, no. 1 (1971): 23-57.

Uebele, Martin. "National and International Market Integration in the $19^{\text {th }}$ Century: Evidence from Comovement." Explorations in Economic History 48, no. 2 (2011): 226-42.

Uebele, Martin, and Daniel Gallardo-Albarran. "Paving the Way to Modernity. Prussian Roads and Grain Market Integration in Westphalia, 1821-1855." Scandinavian Economic History Review 63 no. 2 (2015): 69-92.

Unger, Johann Friedrich. Von der Ordnung der Fruchtpreise, und deren Einflusse in die wichtigsten Angelegenheiten des menschlichen Lebens. Göttingen: No publisher, 1752.

Van Bavel, Baas. The Invisible Hand? Oxford: Oxford University Press, 2016.

Van Bochove, Christiaan. "Market Integration and the North Sea System." In The Dynamics of Economic Culture in the North Sea and Baltic Region in the Late Middle Ages and Early Modern Period, edited by Hanno Brand and Leos Müller, 155-69. Hilversum: Uitgeverij Verloern, 2007.

Van Crefeld, M. Supplying War: Logistics from Wallenstein to Patton. Cambridge, UK: Cambridge University Press, 2004. 
Van Zanden, Jan Luiten, and Milja van Tielhof. "Roots of Growth and Productivity Change in Dutch Shipping Industry." Explorations in Economic History 46, no. 4 (2009): 389-403.

Velkar, Aashish. “'Deep' Integration of 19th Century Grain Markets: Coordination and Standardisation in a Global Value Chain.” LSE Working Papers in Economics No. 145/10, London, 2010.

Vinnal, Hannes. "Cost-Distance Ratio in Change: Transmission Rates of Commercial Correspondence in the North and Baltic Sea Region, 1732-1808." Scandinavian Economic History Review (2018): 1-18.

Volckart, Oliver. "The Influence of Information Costs on the Integration of Financial Markets: Northern Europe, 1350-1560." In Information Flows: New Approaches in the Historical Study of Business Information, edited by Leos Müller and Jari Ojala, 31-62. Helsinki: Finnish Literature Society, 2007.

Weber, Johannes. "'Unterthenige Supplication Johann Caroli/Buchtruckers': Der Beginn gedruckter politischer Wochenzeitungen im Jahre 1605." Archiv für Geschichte des Buchwesens 38 (1992): 257-65.

—. "Straßburg 1605: Die Geburt der Zeitung." Jahrbuch für Kommunikationsgeschichte 7 (2005): 3-26.

Williams, Kevin. Read All About It! A History of the British Newspaper. London: Routledge, 2009.

Wilson, P. H. Europe's Tragedy: A New History of the Thirty Years War. London: Penguin, 2010.

Wüllen, W. A. von. "Nordhäusische monatliche Fruchtpreise, vom Monat May 1668. bis dahin 1771." Hannoverisches Magazin (1771): 657-724.

Note: Maps throughout this article were created using ArcGIS® software by Esri. ArcGIS ${ }^{\circledR}$ and ArcMap ${ }^{\mathrm{TM}}$ are the intellectual property of Esri and are used herein under license. Copyright (C) Esri. All rights reserved. For more information about Esri® software, please visit www.esri.com. 